\title{
Active Submarine Volcanism on the Society Hotspot Swell (West Pacific): A Geochemical Study
}

\author{
C.W. Devey, ${ }^{1.2}$ F. Albarede, ${ }^{1}$ J.-L. Cheminée, ${ }^{3}$ A. Michard, ${ }^{1}$ \\ R. MÜHE, ${ }^{4}$ AND P. STOFFERS ${ }^{4}$
}

\begin{abstract}
The present work deals with the petrography and geochemistry of lavas dredged from five active submarine volcanoes (named Mehetia, Moua Pihaa, Rocard. Teahitia, and Cyana) from the southeast end of the Society Islands hotspot trace. Most samples are basic and alkaline, ranging from 16 to $5 \mathrm{wt}$ $\% \mathrm{MgO}$, with about $5 \%$ normative nepheline. Fractionation modelling based on major and minor compatible element variations suggests that olivine and minor clinopyroxene were the major fractionating phases and implies a maximum range of fractionation of 30-35\%. Rocard and Cyana have yielded more evolved, trachy-phonolitic, glassy samples. These evolved samples are thought to be derived by removal of $70 \%$ cumulate from the basalts. Both basaltic and phonolitic samples are incompatible-element enriched, with $\mathrm{La} / \mathrm{Yb} N \approx 15$ in most of the basalts. The trachy-phonolite patterns show middle rare earth element (REE) depletion and negative Eu anomalies. The Moua Pihaa basalts have flatter patterns than the other basalts $(\mathrm{La} / \mathrm{Yb} N=7.5-12.4)$. All samples, with the exception of a sample from Moua Pihaa which has elevated ${ }^{206} \mathrm{~Pb} / 204 \mathrm{~Pb}$, fall on linear Sr-Nd-Pb isotopic arrays, suggesting two end-member mixing. The most depleted end-member is shown to be a pristine ocean island basalt magma with no detectable contribution from a depleted, mid-ocean ridge basalt (MORB) upper mantle. The flatter REE patterns and higher ${ }^{206} \mathrm{~Pb} / 204 \mathrm{~Pb}$ of the Moua Pihaa sample are taken to indicate a more depleted, U-enriched (high $\mu$ ) component in its source. This component may be altered oceanic crust. The $\mathrm{Sr}$ isotopic variations in the samples excluding Moua Pihaa correlate positively with $\mathrm{Rb} / \mathrm{Nb}, \mathrm{Pb} / \mathrm{Ce}$, and $\mathrm{SiO}_{2}$ variations, indicating a component of mantle enriched by injection of material from a subducted oceanic slab. Correlation of ${ }^{207} \mathrm{~Pb} /{ }^{204} \mathrm{~Pb}$ with ${ }^{87} \mathrm{Sr}{ }^{866} \mathrm{Sr}$ suggests that the subducted material is geochemically old. Mapping the geochemical variations shows that the contribution to the lavas from the subduction component is greater over the north of the hotspot than in the south. The absence of a MORB component in the Society magmatism, the small volumes of the Polynesian hotspot volcanoes, and the lack of more intense volcanic activity near the center of the Pacific Superswell, all lead us to conclude that the latter is unlikely to be caused by a large convective plume. The Superswell is more probably located above a region in the asthenospheric mantle which, due to its higher content of recycled continental debris, is anomalously hot.
\end{abstract}

\section{INTRODUCTION}

Little is known about the geochemistry of the volumetrically most important, submarine stages of ocean island volcano formation. Only Loihi seamount in Hawaii has been studied in any detail [Moore et al., 1982; Craig, 1983], and it is perhaps somewhat exceptional as it is built on the flanks of an older volcano (Mauna Loa). By contrast, a great deal is known of the subaerial portions of ocean island volcanoes. The basalts they are composed of (ocean island basalts, or OIB) are compositionally different from mid-ocean ridge basalt (MORB). Some of these differences can be explained by differences in the degree and depth of partial melting at which the magmas were formed. Isotopic differences between OIB and MORB imply that

\footnotetext{
${ }^{1}$ Centre de Recherches Pétrographiques et Géochimiques, Vandoeuvre lès Nancy, France.

2 Now at Geologogisches Institut der Universität Kiel, Federal Republic of Germany.

3 Observatoire Volcanologique, Institut Physique du Globe Paris, Paris, France.

${ }^{4}$ Geologisches Institut der Universität Kiel, Federal Republic of Germany.
}

Copyright 1990 by the American Geophysical Union.

Paper number 89JB03188.

0148-0227/90/89JB-03188\$05.00 their sources are distinct and that OIB sources have, in many cases, evolved with higher ("enriched") $\mathrm{Rb} / \mathrm{Sr}$, $\mathrm{Nd} / \mathrm{Sm}, \mathrm{U} / \mathrm{Pb}$, and $\mathrm{Th} / \mathrm{Pb}$ for long periods. Previous studies have highlighted the isotopic and elemental heterogeneities in ocean island volcanoes [e.g., White and Hofmann, 1982; Dupré and Allegre, 1983] and shown them to be generated from mixtures between different sources [e.g., Zindler et al., 1982; Zindler and Hart, 1986]. What geological processes have led to these differences, and where the OIB source lies relative to the supposedly shallow-lying MORB source, are presently the subject of debate. Candidates for OIB sources range from primitive, chondritic mantle, through metasomatic fluids, to subducted sediment or altered oceanic crust [Hofmann and White, 1982] and from having a position underlying the MORB source (layered mantle model) to being intermixed with it (plum pudding or marble cake models). Recent elemental [Hofmann et al., 1986] or combined isotopic and elemental [Palacz and Saunderrs, 1986; Dupuy et al., 1987] ocean island volcano studies have added important new constraints by highlighting the elemental signatures related to the isotopic variations.

Ocean island volcanoes are thought to occur above thermal anomalies (hotspots) in the mantle [Morgan, 1972]. It is these hotspots which may contribute the enriched component to the magmas. The chemical nature and percentage involvement of the hotspot components seem to vary geographically. Hart [1984] provided contoured maps of the oceans to show where at least one 


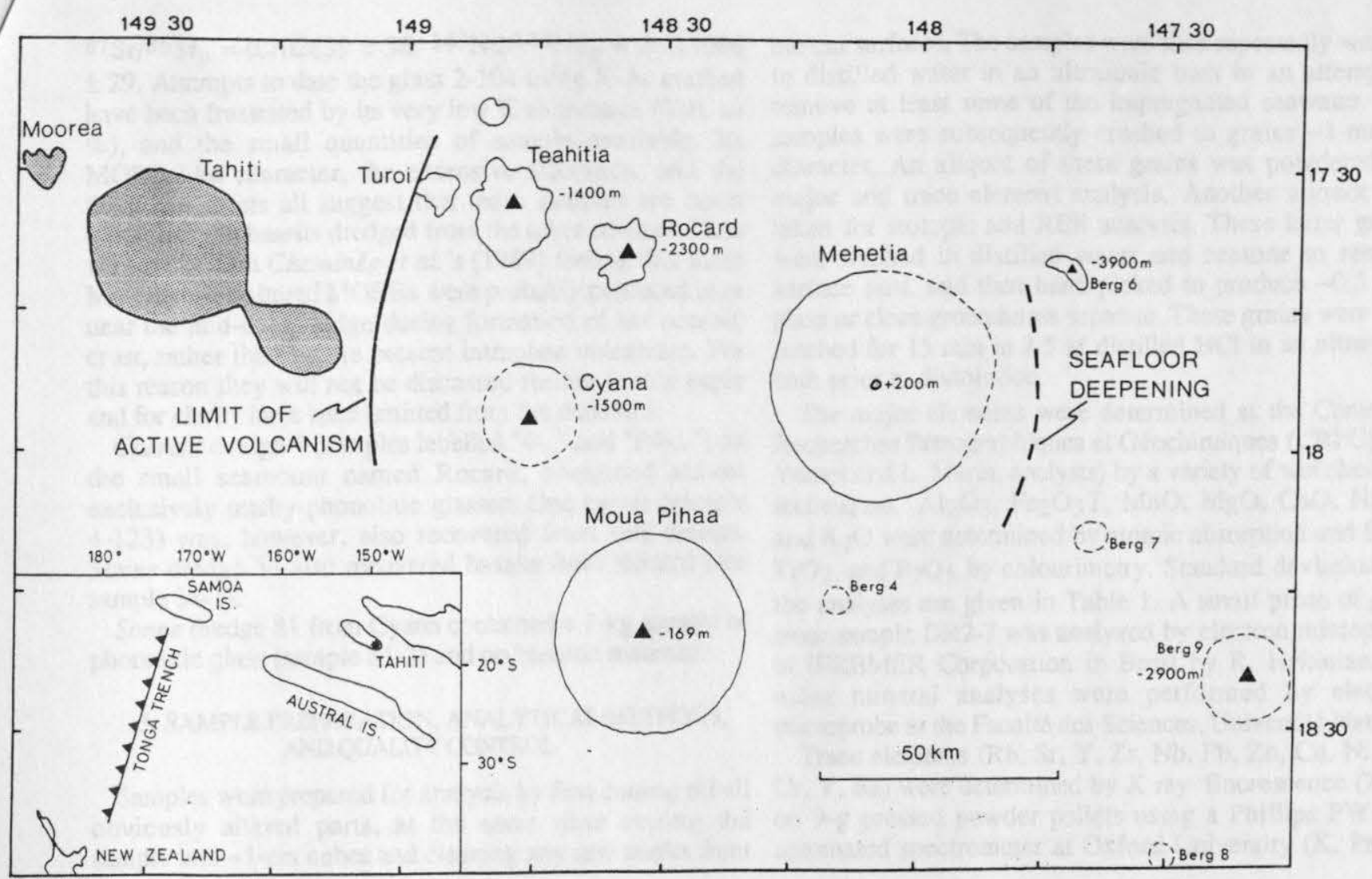

Fig 1. Topographic features at the southeast end of the Society hotspot trace. Bathymetric data were collected during the Jean Charcot and Sonne cruises [Cheminée et al., 1989; Stoffers et al., 1987]. Limits of active volcanism constrained to the west to pass between the extinct Tahiti and the active Teahitia, and to the east by deepening of the seafloor east of Mehetia [Cheminée et al., 1989].

component (the Dupal component, recognized most especially by anomalously high ${ }^{87} \mathrm{Sr} / 86 \mathrm{Sr}, 207 \mathrm{~Pb} / 204 \mathrm{~Pb}$, and $208 \mathrm{~Pb} / 204 \mathrm{~Pb}$ isotopic ratios) is most prevalent.

We present here a detailed petrographic, chemical, and isotopic investigation of the active submarine volcanism at one Dupal OIB site, the Society Islands of the southwestern Pacific. Samples were dredged in 1986 aboard the R/V Jean Charcot and in 1987 aboard R/V Sonne around Tahiti. The sampling sites were first chosen because of intense seismic activity in the area [Talandier and Okal, 1984; Okal et al., 1980]. Subsequent Sea Beam mapping confirmed the existence of volcanic edifices associated with the seismic epicenters [Cheminée et al., 1989; Stoffers et al., 1987; R. Hékinian, manuscript in preparation, 1990]. Four of these edifices (Teahitia, Rocard, Mehetia, and a seamount north of Teahitia, see Figure 1) were sampled in 1986 and 1987, while other volcanoes, including the $3000 \mathrm{~m}$-high Moua Pihaa, were sampled for the first time in 1987.

\section{SAMPLE LOCATION AND DESCRIPTION}

The island of Tahiti lies at the southeastern end of the 300-km-long Society Island archipelago in French Polynesia. It is no longer volcanically active, the last activity having occurred about 440 thousand years ago [Duncan and McDougall, 1976; Brousse et al., 1985]. The oldest rocks in the archipelago come from Maupiti, the northwesternmost island, where Duncan and McDougall
[1976] found ages of 4.5 Ma. The islands are built on circa $70 \mathrm{Ma}$ crust and are thought to be related to the activity of the Society hotspot, the present products of which are being erupted to the southeast of Tahiti [Talandier and Okal, 1984; Cheminée et al., 1989]. Figure 1 shows the relative locations of all the edifices, together with their sizes and is a compilation of the work of Cheminée et al. [1989] and Stoffers et al. [1987]. The limits of the active volcanism have been drawn in the west between the extinct island of Tahiti and the nearest known active volcanoes Teahitia and Cyana and in the east just to the east of Mehetia where Cheminée et al. [1989] report a marked deepening of the seafloor. Most of the rocks recovered were basalts. Charcot dredge 2, collected from the unnamed volcano north of Teahitia (Figure 1), contained mainly $\mathrm{Mn}$ nodules and altered basalt covered in Mn crusts, although one fresh basaltic sample (2-1) was recovered. Between the altered basalt and the Mn crusts, a thin rind of glass was sometimes preserved. The small quantities of this material available from any one sample meant that we had to analyze major and rare earth elements (REE) on one sample (analysis 2-7, Tables 2 and 3 ) and isotopic ratios on a different sample (analysis 2-104, Table 3). The hand specimen similarities of these two samples suggest that they are pieces broken from the same block. To avoid ambiguity, however, we have maintained the two sample numbers. The 2-7/2-104 glass has MORB-like geochemical characteristics, as reported by Cheminée et al. [1989] with LREE-depleted REE curves, and isotopic values of 
${ }^{87} \mathrm{Sr} / 86 \mathrm{Sr}_{\mathrm{p}}=0.702839 \pm 36,143 \mathrm{Nd} / 144 \mathrm{Nd} \mathrm{p}=0.513086$ \pm 29 . Attempts to date the glass $2-104$ using $\mathrm{K}$ - $\mathrm{Ar}$ method have been frustrated by its very low $\mathrm{K}$ abundance $(0.01 \mathrm{wt}$ $\%$, and the small quantities of sample available. Its MORB-like character, the extensive alteration, and the thick Mn crusts all suggest that these samples are much older than the basalts dredged from the other edifices. Thus we concur with Cheminée et al.'s [1989] feeling that these Mn-encrusted altered MORBs were probably produced at or near the mid-ocean ridge during formation of the oceanic crust, rather than by the present intraplate volcanism. For this reason they will not be discussed further in this paper and for clarity have been omitted from the diagrams.

Charcot dredge 4 (samples labelled "4-..".and "P4-...") on the small seamount named Rocard, contained almost exclusively trachy-phonolitic glasses. One basalt (sample 4-123) was, however, also recovered from this dredge. Sonne dredge 34 also recovered basalts from Rocard (see sample 34-1).

Sonne dredge 81 from Cyana contained a 1-kg sample of phonolitic glass (sample 81-3) and no basaltic material.

\section{SAMPLE PREPARATION, ANALYTICAL METHODS, AND QUALTTY CONTROL}

Samples were prepared for analysis by first cutting off all obviously altered parts, at the same time cutting the sample into $\sim 1-\mathrm{cm}$ cubes and cleaning any saw marks from the cut surfaces. The samples were then repeatedly washed in distilled water in an ultrasonic bath in an attempt to remove at least some of the impregnated seawater. The samples were subsequently crushed to grains $\sim 1-\mathrm{mm}$ in diameter. An aliquot of these grains was powdered for major and trace element analysis. Another aliquot was taken for isotopic and REE analysis. These latter grains were washed in distilled water and acetone to remove surface dust, and then hand-picked to produce $\sim 0.5 \mathrm{~g}$ of glass or clean groundmass separate. These grains were then leached for $15 \mathrm{~min}$ in $2.5 \mathrm{M}$ distilled $\mathrm{HCl}$ in an ultrasonic bath prior to dissolution.

The major elements were determined at the Centre de Recherches Pétrographiques et Géochimiques (CRPG) (M. Vernet and L. Marin, analysts) by a variety of wet chemical techniques. $\mathrm{Al}_{2} \mathrm{O}_{3}, \mathrm{Fe}_{2} \mathrm{O}_{3} \mathrm{~T}, \mathrm{MnO}, \mathrm{MgO}, \mathrm{CaO}, \mathrm{Na}_{2} \mathrm{O}$, and $\mathrm{K}_{2} \mathrm{O}$ were determined by atomic absorption and $\mathrm{SiO}_{2}$, $\mathrm{TiO}_{2}$, and $\mathrm{P}_{2} \mathrm{O}_{5}$ by colourimetry. Standard deviations on the analyses are given in Table 1. A small piece of glass from sample DR2-7 was analyzed by electron microprobe at IFREMER Corporation in Brest by R. Hekinian. All other mineral analyses were performed by electron microprobe at the Faculté des Sciences, Université Nancy I.

Trace elements (Rb, Sr, Y, Zr, $\mathrm{Nb}, \mathrm{Pb}, \mathrm{Zn}, \mathrm{Cu}, \mathrm{Ni}, \mathrm{Co}$, $\mathrm{Cr}, \mathrm{V}, \mathrm{Ba}$ ) were determined by $\mathrm{X}$ ray fluorescence (XRF) on 9-g pressed powder pellets using a Phillips PW1400 automated spectrometer at Oxford University (K. Parish,

TABLE 1a. Major and Selected Trace Element Analyses of Society Seamount Samples for Mehetia and Dredge 2

\begin{tabular}{|c|c|c|c|c|c|c|c|c|c|c|c|}
\hline & \multirow[b]{2}{*}{$\sigma$, rel. $\%$} & \multicolumn{8}{|c|}{ Mehetia } & \multicolumn{2}{|c|}{ Dredge 2} \\
\hline & & P1-1 & $\mathrm{P} 2-5$ & P3-1 & P3-3 & P3-4 & P3-5 & P3-101 & P3-115 & $2-1$ & $2-7$ \\
\hline $\mathrm{SiO}_{2}$ & 0.4 & 45.30 & 45.29 & 44.94 & 45.40 & 43.06 & 43.13 & 44.23 & 43.32 & 44.05 & 47.17 \\
\hline $\mathrm{Al}_{2} \mathrm{O}_{3}$ & 2.0 & 13.33 & 13.37 & 12.55 & 13.75 & 14.45 & 10.08 & 9.76 & 10.03 & 11.16 & 18.34 \\
\hline $\mathrm{Fe}_{2} \mathrm{O}_{3}$ & 3.0 & 3.82 & 3.71 & 3.34 & 4.06 & 4.40 & 2.75 & 2.15 & 2.73 & 3.37 & \\
\hline $\mathrm{FeO}$ & 0.5 & 7.71 & 8.12 & 8.55 & 7.77 & 7.84 & 9.67 & 10.26 & 9.69 & 8.86 & 8.34 \\
\hline $\mathrm{MnO}$ & 5.0 & 0.17 & 0.18 & 0.19 & 0.17 & 0.18 & 0.17 & 0.18 & 0.18 & 0.19 & 0.04 \\
\hline $\mathrm{MgO}$ & 1.0 & 7.79 & 7.86 & 8.28 & 7.33 & 5.60 & 15.94 & 16.81 & 16.36 & 12.14 & 10.26 \\
\hline $\mathrm{CaO}$ & 1.0 & 9.75 & 9.93 & 11.22 & 9.94 & 9.80 & 8.97 & 8.69 & 8.77 & 9.92 & 11.75 \\
\hline $\mathrm{Na}_{2} \mathrm{O}$ & 1.6 & 3.30 & 3.30 & 3.00 & 3.40 & 3.40 & 2.50 & 2.33 & 2.39 & 2.90 & 2.51 \\
\hline $\mathrm{K}_{2} \mathrm{O}$ & 1.5 & 2.00 & 1.96 & 1.67 & 1.95 & 2.12 & 2.72 & 1.27 & 1.30 & 1.51 & 0.01 \\
\hline $\mathrm{TiO}_{2}$ & 1.8 & 3.73 & 3.72 & 3.60 & 3.89 & 4.14 & 2.96 & 2.76 & 2.81 & 3.35 & 0.73 \\
\hline $\mathrm{P}_{2} \mathrm{O}_{5}$ & 3.0 & 0.66 & 0.66 & 0.64 & 0.66 & 0.72 & 0.53 & 0.47 & 0.47 & 0.59 & \\
\hline Total & & 97.56 & 98.10 & 97.98 & 98.32 & 95.71 & 99.42 & 99.81 & 99.09 & 98.04 & 99.15 \\
\hline Mg\# & 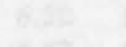 & 0.60 & 0.59 & 0.60 & 0.58 & 0.50 & 0.74 & 0.74 & 0.74 & 0.68 & 0.72 \\
\hline $\mathrm{Ba}$ & $<5$ & 467 & 429 & 416 & 452 & 418 & 365 & 372 & 381 & 375 & \\
\hline $\mathrm{Rb}$ & $<5$ & 49 & 49 & 41 & 48 & 44 & 33 & 33 & 32 & 38 & \\
\hline Sr & $<5$ & 774 & 769 & 786 & 783 & 819 & 658 & 607 & 608 & 721 & If \\
\hline$Y$ & $<5$ & 36 & 35 & 34 & 36 & 38 & 29 & 22 & 23 & 31 & \\
\hline $\mathrm{Zr}$ & $<5$ & 354 & 351 & 319 & 350 & 338 & 263 & 243 & 245 & 292 & \\
\hline $\mathrm{Nb}$ & $<5$ & 48 & 48 & 44 & 48 & 51 & 37 & 34 & 34 & 41 & \\
\hline $\mathrm{Pb}$ & $<5$ & 5 & - & - & - & - & - & - & - & 4 & \\
\hline $\mathrm{Zn}$ & $<5$ & 126 & 130 & 130 & 132 & 134 & 130 & 131 & 131 & 128 & \\
\hline $\mathrm{Cu}$ & $<5$ & 59 & 59 & 86 & 61 & 44 & 63 & 62 & 66 & 72 & \\
\hline $\mathrm{Ni}$ & $<5$ & 160 & 172 & 186 & 143 & 58 & 580 & 637 & 613 & 381 & \\
\hline Co & $<5$ & 45 & 54 & 52 & 46 & 45 & 74 & 83 & 83 & 63 & \\
\hline $\mathrm{Cr}_{\mathrm{r}}$ & $<5$ & 249 & 245 & 371 & 195 & 31 & 710 & 840 & 752 & 608 & \\
\hline V & $<5$ & 274 & 280 & 288 & 293 & 324 & 227 & 220 & 213 & 249 & \\
\hline $\begin{array}{l}\text { Samp } \\
\text { the first } \\
\text { numbers } \\
\text { the first } \\
\text { sample } \mathrm{f}\end{array}$ & $\begin{array}{l}\text { nbers le } \\
\text { er. Sam } \\
\text { ining wi } \\
\text { er and }\end{array}$ & $\begin{array}{l}15 \text { bef } \\
\text { mbers } \\
\text { nbers } g \\
\text { hen. A }\end{array}$ & the hy & $\begin{array}{l}\text { en are } \\
\text { th a "P } \\
\text { are fr } \\
s \text { an ele }\end{array}$ & the $C$ & $\begin{array}{l}\text { cot crui } \\
\text { rcot sa } \\
\text { cruise, } \\
\text { obe an }\end{array}$ & $\begin{array}{l}\text { and ori } \\
\text { es, and } \\
\text { origina } \\
\text { s of gla } \\
\text { he table }\end{array}$ & $\begin{array}{l}\text { Illy had } \\
\text { re initi } \\
\text { had the } \\
\text { separate } \\
\text { gnifies }\end{array}$ & $\begin{array}{l}\text { letters } \\
\text { labelle } \\
\text { ters "D } \\
\text { rom an } \\
\text { lement }\end{array}$ & $\begin{array}{l}\mathrm{DR}^{\prime} \text { or " } \\
\text { "DR1 P.. } \\
\text { or "GT } \\
\text { orered, M } \\
\text { ot measu }\end{array}$ & $\begin{array}{l}\text { Z" befor } \\
. " \text { Sampl } \\
\text { ". betwee } \\
\text {-encruste } \\
\text { ed. A das }\end{array}$ \\
\hline & & & & & & & & & & & \\
\hline
\end{tabular}


TABLE $1 b$. Major and Selected Trace Element Analyses of Society Seamount Samples for Teahitia

Teahitia

\begin{tabular}{|c|c|c|c|c|c|c|c|c|c|c|c|c|c|c|c|c|c|}
\hline & $3-1$ & $3-2$ & 3.3 & 3.5 & $3-7$ & $3-8$ & $3-100$ & 3-101 & $3-113$ & $5-1$ & $5-5$ & $9-1$ & $9-3$ & $9-1 \mathrm{CD}$ & $9-2 \mathrm{CD}$ & $20-1$ & $22-1$ \\
\hline$\overline{\mathrm{SiO}_{2}}$ & 45.35 & 45.49 & 44.15 & 46.55 & 45.30 & 43.52 & 44.17 & 43.64 & 45.50 & 45.80 & 45.58 & 47.15 & 43.89 & 45.11 & 42.87 & 45.77 & 47.81 \\
\hline $\mathrm{Al}_{2} \mathrm{O}_{3}$ & 12.22 & 12.14 & 11.10 & 13.39 & 11.36 & 10.93 & 12.03 & 10.56 & 11.67 & 13.62 & 13.65 & 12.80 & 9.87 & 11.92 & 11.65 & 13.40 & 15.56 \\
\hline $\mathrm{Fe}_{2} \mathrm{O}_{3}$ & 3.35 & 3.13 & 3.13 & 3.23 & 2.88 & 3.02 & 3.67 & 2.77 & 2.81 & 3.23 & 3.14 & 2.61 & 2.32 & 2.94 & 3.49 & 2.81 & 2.60 \\
\hline $\mathrm{FeO}$ & 8.64 & 8.90 & 9.57 & 8.29 & 9.34 & 9.90 & 9.07 & 10.13 & 9.33 & 7.76 & 7.84 & 8.31 & 9.97 & 8.82 & 9.16 & 8.17 & 7.33 \\
\hline $\mathrm{MnO}$ & 0.17 & 0.17 & 0.18 & 0.15 & 0.16 & 0.18 & 0.18 & 0.18 & 0.17 & 0.17 & 0.17 & 0.15 & 0.17 & 0.16 & 0.17 & 0.17 & 0.15 \\
\hline $\mathrm{MgO}$ & 9.27 & 9.77 & 12.33 & 6.62 & 12.08 & 12.78 & 9.73 & 14.26 & 11.28 & 8.28 & 8.50 & 9.91 & 15.98 & 11.65 & 11.07 & 8.87 & 5.77 \\
\hline $\mathrm{CaO}$ & 10.17 & 10.11 & 10.31 & 10.92 & 9.34 & 10.49 & 11.06 & 9.71 & 9.55 & 8.70 & 8.59 & 8.80 & 9.59 & 9.42 & 10.07 & 8.46 & 7.78 \\
\hline $\mathrm{Na}_{2} \mathrm{O}$ & 2.80 & 2.70 & 2.40 & 3.00 & 2.60 & 2.40 & 2.65 & 2.24 & 2.54 & 3.99 & 4.00 & 2.80 & 2.25 & 2.82 & 2.79 & 4.03 & 3.87 \\
\hline $\mathrm{K}_{2} \mathrm{O}$ & 1.60 & 1.56 & 1.27 & 1.79 & 1.49 & 1.27 & 1.44 & 1.20 & 1.52 & 2.58 & 2.54 & 2.21 & 1.16 & 1.71 & 1.84 & 2.55 & 2.92 \\
\hline $\mathrm{TiO}_{2}$ & 3.62 & 3.65 & 3.55 & 3.97 & 3.39 & 3.51 & 3.95 & 3.30 & 3.46 & 3.37 & 3.34 & 2.98 & 2.84 & 3.20 & 3.59 & 3.32 & 3.23 \\
\hline $\mathrm{P}_{2} \mathrm{O}_{5}$ & 0.59 & 0.58 & 0.43 & 0.64 & 0.51 & 0.44 & 0.49 & 0.38 & 0.55 & 0.65 & 0.64 & 0.59 & 0.44 & 0.62 & 0.65 & 0.63 & 0.81 \\
\hline Total & 97.78 & 98.20 & 98.42 & 98.55 & 98.45 & 98.44 & 99.31 & 99.13 & 99.24 & 99.33 & 99.15 & 99.41 & 99.53 & 99.60 & 99.22 & 99.29 & 99.10 \\
\hline Mg\# & 0.63 & 0.64 & 0.68 & 0.56 & 0.68 & 0.68 & 0.62 & 0.71 & 0.67 & 0.62 & 0.63 & 0.66 & 0.74 & 0.68 & 0.66 & 0.64 & 0.56 \\
\hline $\mathrm{Ba}$ & 379 & 410 & 437 & 503 & 387 & 383 & 467 & 392 & 434 & 733 & 704 & 576 & 345 & 450 & 622 & 714 & 764 \\
\hline $\mathrm{Rb}$ & 34 & 34 & 36 & 36 & 32 & 31 & 35 & 30 & 32 & 62 & 62 & 46 & 30 & 38 & 44 & 62 & 57 \\
\hline Sr & 688 & 708 & 700 & 793 & 642 & 585 & 652 & 546 & 658 & 897 & 878 & 737 & 568 & 776 & 749 & 889 & 904 \\
\hline Y & 31 & 31 & 32 & 35 & 30 & 30 & 28 & 22 & 26 & 32 & 33 & 28 & 25 & 28 & 31 & 33 & 32 \\
\hline $\mathrm{Zr}$ & 280 & 279 & 289 & 308 & 262 & 234 & 262 & 217 & 269 & 381 & 377 & 308 & 223 & 279 & 280 & 374 & 325 \\
\hline $\mathrm{Nb}$ & 34 & 34 & 36 & 38 & 31 & 35 & 38 & 32 & 31 & 5 & 58 & 37 & 32 & 36 & 44 & 58 & 51 \\
\hline $\mathrm{Pb}$ & 3 & - & - & 4 & 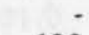 & - & - & - & - & 10 & 8 & 5 & 5 & 8 & 7 & 8 & 7 \\
\hline $\mathrm{Zn}$ & 122 & .128 & 128 & 130 & 128 & 124 & 127 & 127 & 129 & 134 & 133 & 125 & 121 & 128 & 130 & 132 & 119 \\
\hline $\mathrm{Cu}$ & 75 & 73 & 71 & 78 & 63 & 74 & 74 & 66 & 64 & 45 & 51 & 49 & 58 & 56 & 50 & 39 & 34 \\
\hline $\mathrm{Ni}$ & 221 & 255 & 225 & 116 & 366 & 380 & 256 & 456 & 337 & 193 & 200 & 275 & 540 & 348 & 268 & 220 & 87 \\
\hline Co & 49 & 54 & 57 & 44 & 72 & 69 & 56 & 79 & 61 & 51 & 49 & 56 & 78 & 64 & 64 & 49 & 36 \\
\hline $\mathrm{Cr}$ & 367 & 390 & 381 & 221 & 517 & 570 & 419 & 637 & 488 & 296 & 310 & 507 & 808 & 545 & 498 & 317 & 139 \\
\hline V & 260 & 261 & 260 & 284 & 243 & 275 & 297 & 265 & 248 & 242 & 240 & 230 & 230 & 231 & 273 & 234 & 212 \\
\hline
\end{tabular}

See Table 1a footnotes.

TABLE 1c. Major and Selected Trace Element Analyses of Society Seamount Samples for Rocard, Moua Pihaa, and Cyana

\begin{tabular}{|c|c|c|c|c|c|c|c|c|c|c|c|c|c|c|c|}
\hline & \multicolumn{10}{|c|}{ Rocard } & \multicolumn{4}{|c|}{ Moua Pihaa } & \multirow{2}{*}{$\begin{array}{l}\text { Cyana } \\
81-3 \\
\end{array}$} \\
\hline & P4-3 & $4-2$ & $4-3$ & $4-8$ & $4-113$ & $4-115$ & $4-123$ & $4-124$ & $4-126$ & $34-1$ & $28-1$ & $28-1 \mathrm{CD}$ & $29-1$ & $29-2 \mathrm{CD}$ & \\
\hline$\overline{\mathrm{SiO}_{2}}$ & 57.73 & 58.05 & 57.63 & 56.19 & 56.42 & 57.56 & 46.08 & 57.85 & 57.81 & 46.08 & 43.55 & 44.93 & 42.74 & 42.52 & 59.70 \\
\hline $\mathrm{Al}_{2} \mathrm{O}_{3}$ & 17.35 & 17.33 & 17.65 & 17.73 & 17.30 & 17.34 & 12.74 & 17.31 & 17.50 & 13.29 & 13.72 & 15.02 & 15.07 & 14.76 & 17.17 \\
\hline $\mathrm{Fe}_{2} \mathrm{O}_{3}$ & 1.39 & 1.30 & 1.40 & 1.48 & 1.47 & 1.28 & 3.56 & 1.32 & 1.31 & 3.31 & 4.06 & 6.42 & 4.84 & 4.98 & 1.99 \\
\hline $\mathrm{FeO}$ & 3.94 & 3.96 & 3.85 & 4.38 & 4.31 & 3.95 & 8.25 & 3.86 & 3.84 & 8.00 & 8.26 & 5.38 & 7.71 & 8.21 & 1.98 \\
\hline $\mathrm{MnO}$ & 0.20 & 0.21 & 0.21 & 0.16 & 0.17 & 0.20 & 0.17 & 0.20 & 0.21 & 0.15 & 0.19 & 0.16 & 0.23 & 0.23 & 0.19 \\
\hline $\mathrm{MgO}$ & 1.32 & 1.30 & 1.28 & 2.03 & 1.99 & 1.33 & 8.32 & 1.30 & 1.30 & 8.06 & 6.33 & 4.94 & 5.44 & 5.63 & 1.08 \\
\hline $\mathrm{CaO}$ & 2.08 & 2.04 & 2.12 & 3.18 & 3.10 & 2.13 & 10.39 & 2.11 & 2.09 & 9.44 & 12.18 & 11.20 & 9.63 & 9.51 & 1.42 \\
\hline $\mathrm{Na}_{2} \mathrm{O}$ & 6.00 & 6.30 & 6.20 & 5.50 & 5.31 & 6.07 & 2.68 & 6.21 & 6.16 & 3.04 & 3.01 & 3.45 & 4.68 & .61 & 6.99 \\
\hline $\mathrm{K}_{2} \mathrm{O}$ & 5.74 & 5.75 & 5.67 & 5.48 & 5.44 & 5.73 & 1.69 & 5.71 & 5.72 & 2.10 & 1.07 & 1.22 & 1.96 & 1.90 & 5.30 \\
\hline $\mathrm{TiO}_{2}$ & 0.84 & 0.83 & 0.82 & 1.33 & 1.32 & 0.84 & 3.75 & 0.83 & 0.81 & 3.60 & 3.41 & 3.55 & 4.36 & 4.48 & 0.61 \\
\hline $\mathrm{P}_{2} \mathrm{O}_{5}$ & 0.57 & 0.54 & 0.56 & 0.55 & 0.82 & 0.55 & 0.60 & 0.54 & 0.54 & 0.65 & 0.52 & 0.54 & 0.80 & 0.81 & 0.62 \\
\hline Total & 97.16 & 97.61 & 97.39 & 98.01 & 99.23 & 99.04 & 99.38 & 99.21 & 99.28 & 99.67 & 99.36 & 99.36 & 99.21 & 99.36 & 99.24 \\
\hline $\mathrm{Mg} \#$ & 0.35 & 0.35 & 0.35 & 0.43 & 0.43 & 0.36 & 0.61 & 0.35 & 0.35 & 0.61 & 0.53 & 0.48 & 0.49 & 0.48 & 0.38 \\
\hline $\mathrm{Ba}$ & & & & & 824 & & & & 20 & & 291 & 280 & 521 & 525 & 803 \\
\hline $\mathrm{Rb}$ & 138 & 138 & 140 & 108 & 106 & 136 & 36 & 137 & 137 & 44 & 34 & 29 & 53 & 53 & 79 \\
\hline $\mathrm{Sr}$ & 104 & 103 & 104 & 482 & 475 & 112 & 705 & 111 & 104 & 773 & 661 & 645 & 1032 & 1031 & 115 \\
\hline$Y$ & 65 & 67 & 66 & 57 & 52 & 61 & 28 & 60 & 61 & 31 & 34 & 38 & 45 & 43 & 47 \\
\hline $\mathrm{Zx}_{x}$ & 1162 & 1170 & 1185 & 834 & 822 & 1137 & 293 & 1145 & 1148 & 300 & 271 & 304 & 375 & 370 & 850 \\
\hline $\mathrm{Nb}$ & 128 & 129 & 128 & 88 & 86 & 124 & 34 & 126 & 125 & 37 & 41 & 41 & 64 & 62 & 77 \\
\hline $\mathrm{Pb}$ & 19 & 17 & 19 & 13 & 15 & 18 & 5 & 19 & 18 & 5 & 5 & 4 & 4 & 7 & 9 \\
\hline $\mathrm{Zn}$ & 199 & 201 & & 167 & 171 & 202 & 129 & 203 & 204 & 125 & 116 & 115 & 138 & 143 & 123 \\
\hline $\mathrm{Cu}$ & - & - & & - & 4 & 3 & 64 & 3 & 3 & 59 & 130 & 133 & 10 & 9 & 7 \\
\hline $\mathrm{Ni}$ & - & - & & 10 & 7 & 3 & 188 & 2 & 4 & 182 & 84 & 83 & 7 & 8 & 3 \\
\hline Co & - & - & & - & 3 & : & 53 & 1 & - & 48 & 51 & 46 & 30 & 39 & $\therefore$ \\
\hline $\mathrm{Cr}$ & - & - & & 10 & 6 & 4 & 324 & - & 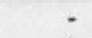 & 341 & 53 & 162 & - & - & 5 \\
\hline V & 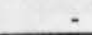 & & & 10 & 9 & 5 & 269 & 3 & 4 & 248 & 349 & 346 & 302 & 317 & 10 \\
\hline
\end{tabular}

See Table 1a footnotes. 
analyst). Repeated analyses of standards suggest analytical precision $( \pm 1 \sigma)$ always $<5 \%$.

Rare earth element concentrations were measured by isotope dilution mass spectrometry at the CRPG using the method of Michard et al. [1986]. Within-run errors $(1 \sigma)$ on the concentrations were always $<1 \%$, except for $\mathrm{Yb}$ which were between 1 and $2 \%$. The standard BCR-1 was also analyzed, and the values determined are given, together with the other REE analyses, in Table 2.

$\mathrm{Sr}, \mathrm{Nd}$, and $\mathrm{Pb}$ isotopic ratios were determined at the
CRPG using the methods of Alibert et al. [1983] and Michard et al. [1985], with the exception of several $\mathrm{Pb}$ analyses (P1-1, P4-3, 2-1, 3-1, 4-2, 3-3) run by P. Vidal at Clermont Ferrand. Isotopic standards run over the last 2 years at the CRPG gave the following unweighted averages: Eimer and Amend ${ }^{87} \mathrm{Sr} / 86 \mathrm{Sr}=0.708033 \pm 23$ (14 runs), BCR-1 ${ }^{143} \mathrm{Nd} /{ }^{144} \mathrm{Nd}=0.512608 \pm 17$ (8 runs). $\mathrm{Pb}$ analyses were performed using the silica gel method in the style of Manhes et al. [1978]. Mass fractionation corrections of 0.008 per amu were systematically applied as

TABLE 2. Rare Earth Element Concentrations in Selected Samples From the Society Seamounts

\begin{tabular}{|c|c|c|c|c|c|c|c|c|c|}
\hline Sample & $\mathrm{La}$ & $\mathrm{Ce}$ & Nd & $\mathrm{Sm}$ & Eur & $\mathrm{Gd}$ & Dy & Er & $\mathrm{Yb}$ \\
\hline \multicolumn{10}{|c|}{ Mehetia } \\
\hline P1-1 & & 105.0 & 54.6 & 11.40 & 3.48 & 9.96 & 6.92 & 2.82 & 2.00 \\
\hline P2-5 & 45.3 & 105.9 & 55.0 & 11.50 & 3.51 & & 7.02 & 2.91 & 1.97 \\
\hline P3-1 & 37.7 & 88.9 & 46.5 & 9.79 & 2.99 & 8.49 & 5.75 & 2.27 & 1.51 \\
\hline P3-3 & 50.2 & 113.0 & 59.0 & 12.17 & 3.70 & 10.61 & 7.34 & 2.97 & 2.12 \\
\hline P3-4 & & 109.6 & 57.7 & 11.98 & 3.71 & 10.59 & 7.50 & 3.11 & 2.20 \\
\hline P3-5 & 41.6 & 101.0 & 50.1 & 10.50 & 3.20 & & 6.09 & 2.49 & 1.63 \\
\hline P3-101 & 33.4 & 78.2 & 41.8 & 8.87 & 2.73 & 7.84 & 5.36 & 2.16 & 1.53 \\
\hline P3-115 & 33.3 & 72.3 & 38.7 & $\begin{array}{c}8.19 \\
\text { Dred }\end{array}$ & 2.52 & 7.18 & 4.90 & 1.98 & 1.33 \\
\hline $2-1$ & 39.3 & 86.4 & 47.3 & 9.96 & 3.04 & 8.68 & 5.93 & 2.33 & 1.56 \\
\hline $2-7$ & & 2.7 & 3.3 & 1.32 & 0.58 & 2.17 & 3.18 & 2.23 & 2.44 \\
\hline Sed1 & & & 19.0 & & & & & & \\
\hline Sed2 & & & 24.4 & & & & & & \\
\hline \multicolumn{10}{|c|}{ Teahitia } \\
\hline 3-1 & 37.0 & 75.3 & 45.7 & 9.96 & 3.50 & 9.01 & 6.13 & 2.42 & 1.68 \\
\hline $3-2$ & & 88.8 & 50.9 & 10.87 & 3.41 & 9.87 & 6.54 & 2.62 & 1.82 \\
\hline $3-3$ & 27.3 & 76.5 & 43.2 & 9.62 & 3.03 & 8.99 & 6.42 & 2.67 & 1.95 \\
\hline $3-5$ & 39.1 & 90.3 & 51.0 & 11.10 & 3.45 & 9.78 & 6.62 & 2.74 & 1.84 \\
\hline $3-8$ & 30.2 & 71.6 & 39.4 & 8.68 & 2.72 & 7.88 & 5.59 & 2.35 & 1.64 \\
\hline $3-100$ & 32.7 & 76.3 & 42.5 & 9.23 & 2.88 & 8.35 & 5.92 & 2.44 & 1.66 \\
\hline $3-101$ & & 65.9 & 35.4 & 7.75 & 2.42 & 6.96 & 4.94 & 2.07 & 1.41 \\
\hline $3-113$ & 32.5 & 76.9 & 43.8 & 9.64 & 3.01 & 8.57 & 5.80 & 2.33 & 1.58 \\
\hline $5-1$ & 49.6 & 123.0 & 60.2 & 11.90 & 3.66 & 10.10 & 7.00 & 2.85 & 2.00 \\
\hline $5-5$ & 43.5 & 110.0 & 51.7 & 10.42 & 3.22 & 8.91 & 6.20 & 2.48 & 1.73 \\
\hline $9-1$ & 31.0 & 98.5 & 51.0 & 10.64 & 3.34 & 9.19 & 6.25 & 2.52 & 1.76 \\
\hline $9-3$ & 32.7 & 78.2 & 42.5 & 9.30 & 2.91 & 8.36 & 5.72 & 2.28 & 1.54 \\
\hline $9-1 C D$ & 36.3 & 85.8 & 46.7 & 9.95 & 3.19 & 8.84 & 5.80 & 2.28 & 1.53 \\
\hline $9-2 \mathrm{CD}$ & 31.7 & 79.2 & 43.3 & 9.34 & 2.92 & 8.34 & 5.64 & 2.26 & 1.50 \\
\hline $20-1$ & 57.8 & 121.8 & 61.0 & 11.90 & 3.67 & 10.10 & 6.91 & 2.78 & 1.95 \\
\hline $22-1$ & 43.1 & 93.9 & 49.7 & 9.83 & 3.24 & 8.47 & 5.85 & 2.42 & 1.79 \\
\hline \multicolumn{10}{|c|}{ Rocard } \\
\hline P4-3 & 84.2 & 241.4 & 110.0 & 19.94 & 4.75 & 15.18 & & $\begin{array}{l}5.43 \\
5.57\end{array}$ & 4.66 \\
\hline $4-2$ & & 243.0 & 110.4 & 19.97 & 4.78 & 14.97 & 11.58 & 5.57 & \\
\hline $4-3$ & 108.3 & 267.0 & 105.3 & 19.40 & 4.62 & 15.11 & 11.68 & 5.49 & 4.91 \\
\hline $4-8$ & & 149.5 & 62.3 & 12.43 & 3.51 & 10.01 & 7.20 & 3.21 & 2.56 \\
\hline $4-113$ & 71.2 & 193.0 & 81.2 & 16.10 & 4.60 & 13.26 & 9.67 & 4.32 & 3.47 \\
\hline $4-124$ & 142.8 & 260.0 & 126.0 & 21.10 & 4.91 & 15.20 & 11.34 & 5.33 & 4.50 \\
\hline $4-126$ & 199.6 & 277.0 & 160.0 & 25.80 & 5.88 & 18.00 & 12.60 & 5.82 & 4.91 \\
\hline $34-1$ & 37.2 & 89.7 & 47.8 & 10.09 & 3.24 & 8.89 & 5.97 & 2.40 & 1.63 \\
\hline \multicolumn{10}{|c|}{ Moua Pihaa } \\
\hline $28-1$ & 25.7 & 60.7 & 35.5 & 8.00 & 2.61 & 7.38 & 5.76 & 2.67 & 2.08 \\
\hline $28-1 C D$ & 24.9 & 61.4 & 37.7 & 8.49 & 2.84 & 8.10 & 6.24 & 2.87 & 2.21 \\
\hline $29-1$ & & 117.0 & 61.6 & 12.80 & 3.96 & 11.40 & 8.30 & 3.68 & 2.76 \\
\hline $29-2 C D$ & 49.5 & 110.5 & 60.2 & 12.50 & 3.92 & 11.20 & 8.24 & 3.61 & 2.70 \\
\hline \multicolumn{10}{|c|}{ Cyana } \\
\hline $81-3$ & & 162 & 71.4 & 12.5 & 3.88 & 9.35 & 7.27 & 3.53 & 3.04 \\
\hline BCR-1 & 21.6 & 52.3 & 28.2 & 6.42 & 1.90 & 6.57 & 6.20 & 3.58 & 3.28 \\
\hline
\end{tabular}


indicated by standards run under the same analytical conditions.

All whole rock analytical data were first processed using a principal components analysis regression technique. The major trends in the data highlighted by this method were then examined in more detail and form the basis for this paper.

\section{RESULTS}

\subsection{Petrography and Mineral Chemistry}

The petrography of some of the samples studied here has been described by Cheminée et al. [1989], and partial phenocryst analyses given. As an estimation of the compositional controls exerted on the lavas by phenocryst fractionation is necessary for the later geochemical discussion, the petrography of the samples will be briefly reviewed here.

4.1.1. Basic rocks. Most of the basic samples are basalts. The basalts contain phenocrysts of olivine, chromite, and occasionally clinopyroxene. Only in sample 28-1CD from Moua Pihaa have plagioclase phenocrysts been found. The basic rocks from the seamounts appear petrographically very similar to the basic rocks of Tahiti based on the petrographic study of Tahiti Island by McBirney and Aoki [1968].

Olivines are by far the most abundant phenocrysts, generally with core compositions lying in the range Fo8185 . These olivine cores are generally more Fo-rich than required by Roeder and Emslie's [1970] equilibrium conditions when compared with the analyses of associated pillow rim glasses. This may be due to lack of complete equilibrium between liquid and crystal cores, possibly as a result of oxide phases precipitating during the rapid quenching of the magmas erupted under water.

Clinopyroxene phenocrysts are seen in the glassy margins of only certain basalt samples (for example, P3-4) but are present in the groundmass, or as microphenocrysts, in the more coarsely crystalline portions of many samples. Exceptions to this are oceanite samples such as 3-101 which contain megacrysts of olivine and rare clinopyroxene, the latter showing complex zoning patterns. In view of the general lack of clinopyroxene phenocrysts in the other samples and the large size of the megacrysts, these samples are interpreted as being cumulate enriched [Cheminée et al., 1989].

4.1.2. Evolved rocks. With the exception of two basaltic samples (4-123, and 34-1) all samples recovered from Rocard are, on the basis of the La Roche et al. [1980] classification, trachy-phonolitic in composition (Table 1). They have been referred to as trachytes by Cheminée et al. [1989]. All samples consist of at least $90 \%$ glass. Phenocrysts of olivine (Fo65-77), biotite, apatite, magnetite, and feldspar are present. Work on the detailed mineral chemistry of these evolved rocks is presently in progress [R. Mühe, manuscript in preparation, 1990]. Two petrographic types have been defined, based on the presence or absence of biotite and feldspar phenocrysts.

The sample from Cyana is even more evolved than those from Rocard, containing almost $60 \% \mathrm{SiO}_{2}$, but all are petrographically very similar. They contain phenocrysts of olivine, biotite, apatite, and small feldspars.

\subsection{Whole Rock Analytical Results}

4.2.1. Basic rocks: Major and trace elements. These rocks have $\mathrm{MgO}$ contents ranging from 5 to $16 \mathrm{wt} \%$. On Teahitia and Mehetia, decreasing $\mathrm{MgO}$ is associated with a slight increase in $\mathrm{SiO}_{2}$ down to about $6 \% \mathrm{MgO}$ (Figure 2). The least magnesian Mehetia sample (P3-4) and all samples from Moua Pihaa have the lowest $\mathrm{SiO}_{2}$ contents. The basaltic samples 4-123 and 34-1 recovered from Rocard, where trachy-phonolites were also found, fall within the trends defined by the basalts from Teahitia and Mehetia.

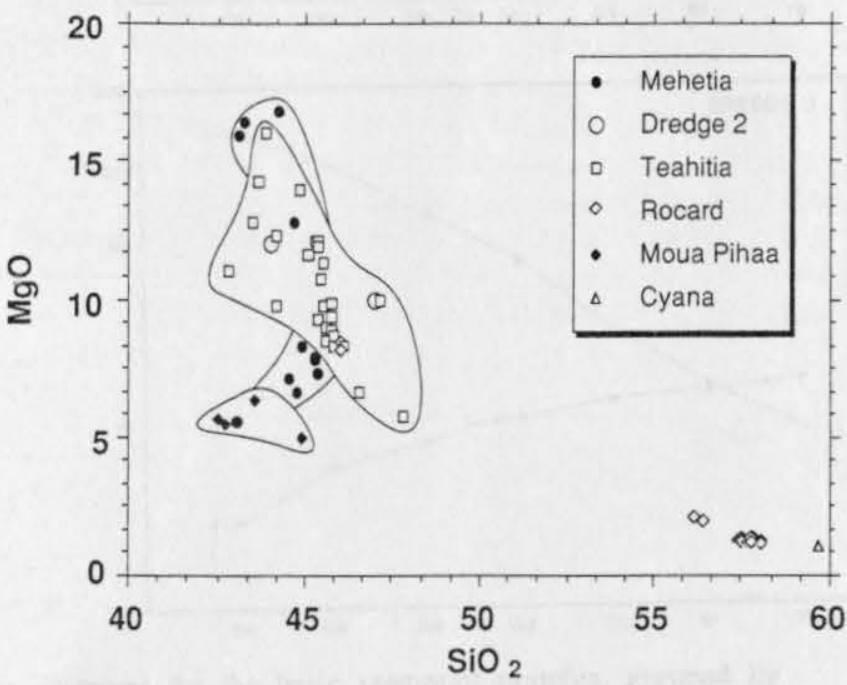

Fig. 2. $\mathrm{MgO}$ versus $\mathrm{SiO}_{2}$ for Society seamounts samples. Data from Table 1 and C.W. Devey (unpublished data, 1989).

All the basic samples are alkaline, and all contain small amounts $(-5 \%)$ of $\mathrm{Ne}$ in the norm. As might be expected from their alkaline nature , the basalts are rich in incompatible elements, and have steep LREE-enriched REE patterns (Figure 3). Alkali basalts from Teahitia, Mehetia, Rocard, and Dredge 2 have REE patterns with similar slopes $\left(\mathrm{Ce} / \mathrm{Yb}_{N}\right.$ between 10 and 16.5$)$ and shapes. REE patterns in Moua Pihaa basalts have lower slopes $\left(\mathrm{Ce} / \mathrm{Yb}_{N}\right.$ between 7 and 11), and in the case of the plagioclasecontaining samples $28-1$ and 28-1CD show small positive Eu anomalies. The other basalts also show slight Eu anomalies, generally positive, of between 1 and $15 \%$, with most around +1 to $+2 \%$.

4.2.2. Trachy-phonolites: Major and trace elements. The trachy-phonolite sample suite from Rocard can be subdivided into two slightly different geochemical groups, both of which are slightly less evolved than the Cyana glass. Rocard samples $4-8$ and $4-113$ form one of the groups and are less silicic and more basic than the other Rocard trachy-phonolites (see Table 1). In the following sections, samples 4-8 and 4-113 are referred to as the "less silicic "group and the rest as the "silicic" group. These geochemical groups correspond to the petrographic groups outlined above

The silicic trachy-phonolites have extremely high alkali contents (11.5-12\% total alkalies) with a $\mathrm{K}_{2} \mathrm{O} / \mathrm{Na}_{2} \mathrm{O}$ ratio of $\sim 0.9$. Incompatible element contents are generally 

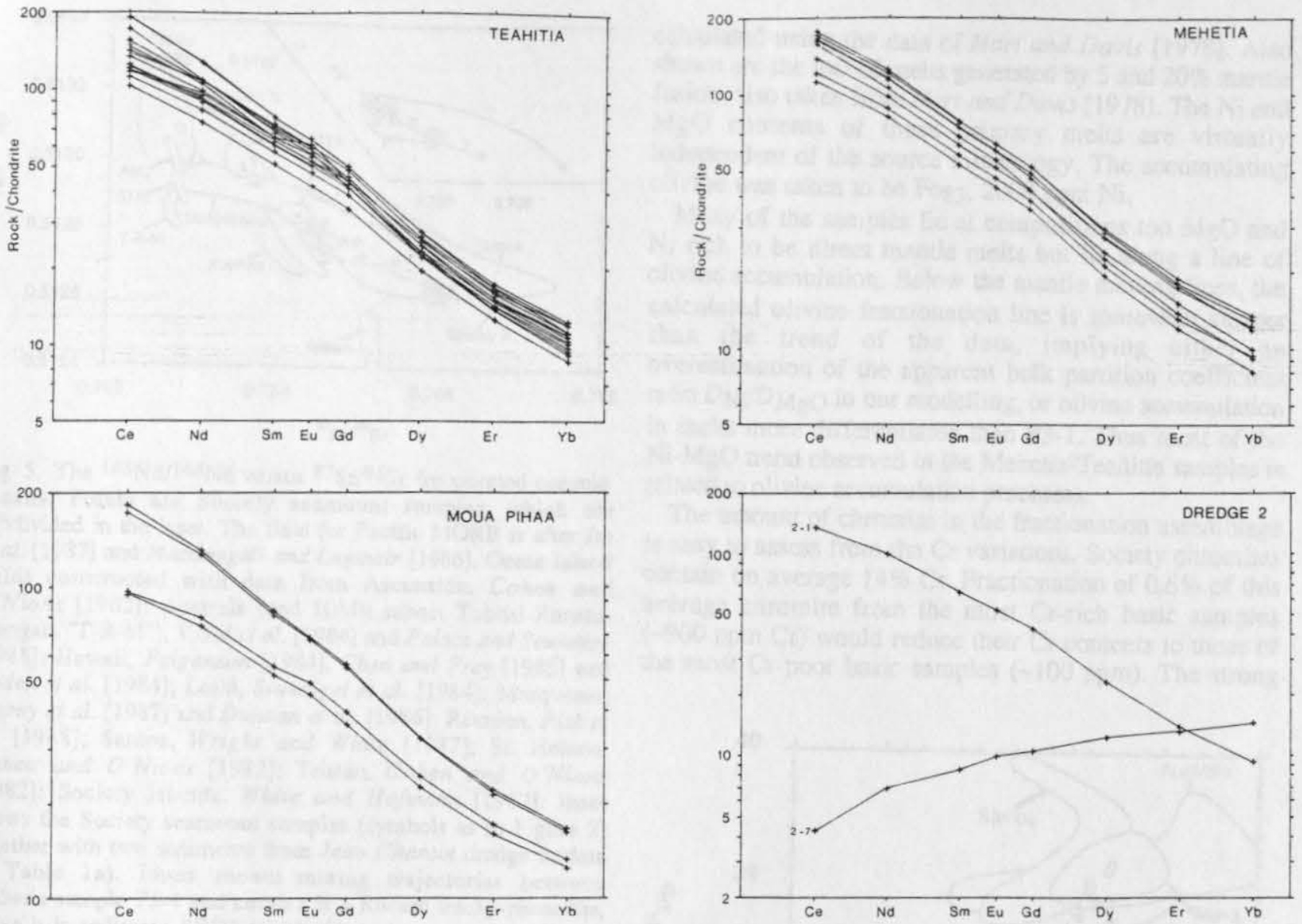

Fig. 3. Chondrite-normalized rare arth element diagrams for the basic seamount samples, grouped by volcano. Normalizing factors are from Evensen et al. [1978].

enriched in comparison to the basalts, by factors of $\sim 4$ for $\mathrm{Zr}$ and $\mathrm{Nb}, 2.5$ for $\mathrm{Y}$. $\mathrm{Sr}$ and $\mathrm{Ba}$ are, however, greatly depleted (by factors of 6 and 2, respectively).

There are marked trace element differences between the low- and the high-silica trachy-phonolite groups. With the exception of $\mathrm{Sr}$ and $\mathrm{Ba}$, the former group is generally poorer in incompatible elements. REE in the two groups are also distinct (Figure 4). The high $\mathrm{SiO}_{2}$ group has higher absolute REE abundances, slightly concave-upward patterns, and marked (up to 20\%) negative Eu anomalies.

4.2.3. Isotopic results. Figure 5 shows the variation in $\mathrm{Sr}$-Nd isotopic ratios of the various seamounts (data from Table 3), together with data on local seafloor sediments (sampled along with the Mn-encrusted MORB in dredge 2, data also in Table 3), Pacific MORB [Ito et al., 1987], and a selection of other ocean islands (references in caption). $\mathrm{Sr}$ and $\mathrm{Nd}$ isotopic ratios were first determined on Society Island samples by White and Hofmann [1982]. Their results are coincident with ours from the seamounts, and their field for the Society Islands as a whole is not substantially modified by our data.

The trachy-phonolite samples from Rocard form a group on their own at high ${ }^{87} \mathrm{Sr} / 86 \mathrm{Sr}$, low ${ }^{143} \mathrm{Nd} / 144 \mathrm{Nd}$. The basalts 4-123 and 34-1 from Rocard are isotopically very similar to Teahitia samples. The field for the Rocard trachy-phonolites is separated from the overlapping fields of the other volcanoes.
$\mathrm{Pb}$ isotopic compositions (Figure 6) of both basalts and trachy-phonolites fall on linear arrays, with the Rocard phonolites at the high $206 \mathrm{~Pb} / 204 \mathrm{~Pb}$ extreme. The Moua

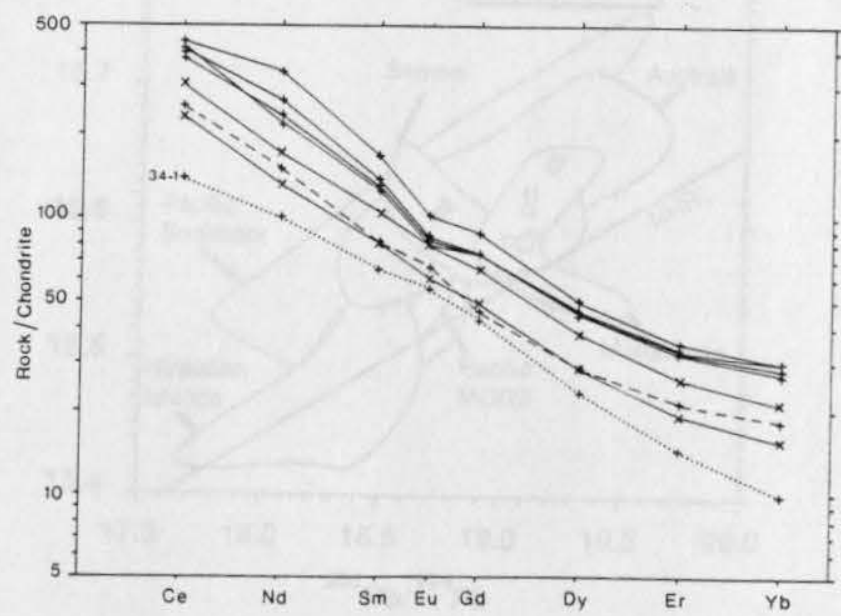

Fig. 4. Chondrite-normalized rare earth element diagram for Rocard and Cyana samples. Samples distinguished as dotted line, basalt 34-1 from Rocard; dashed line, phonolite 81-3 from Cyana; pluses, solid line, silicic Rocard trachyphonolites; crosses, solid line, less silicic Rocard trachyphonolites. Normalizing factors are from Evensen et al. [1978]. 
TABLE 3. Isotopic Ratios, $\mathrm{U}$ and $\mathrm{Pb}$ Concentrations in Selected Society Seamounts Samples

\begin{tabular}{|c|c|c|c|c|c|c|c|}
\hline & ${ }^{87} \mathrm{Sr} / 86 \mathrm{Sr}$ & ${ }^{143} \mathrm{Nd} /{ }^{144} \mathrm{Nd}$ & $206 \mathrm{~Pb} / 204 \mathrm{~Pb}$ & ${ }^{207} \mathrm{~Pb} / 204 \mathrm{~Pb}$ & ${ }^{208} \mathrm{~Pb} / 204 \mathrm{~Pb}$ & $\underset{\mathrm{ppm}}{\mathrm{U}}$ & $\begin{array}{l}\mathrm{Pb} \\
\mathrm{ppm}\end{array}$ \\
\hline P1-1* & $0.704655 \pm 42$ & $0.512757+21$ & Mehetia & & & & \\
\hline P2-5 & $0.704600 \pm 44$ & $0.512823 \pm 21$ & 19.095 & 15.567 & 38.949 & & 5.20 \\
\hline P3-1 & $0.704622 \pm 38$ & $0.512760 \pm 20$ & & & & & $\begin{array}{l}5.05 \\
4.56\end{array}$ \\
\hline P3-3 & $0.704597 \pm 26$ & $0.512804 \pm 21$ & & & & & \\
\hline P3-4 & $0.704276 \pm 49$ & $0.512847 \pm 22$ & 19.057 & 15.561 & 38.751 & & 4.40 \\
\hline P3-5 & $0.704466 \pm 43$ & $0.512809 \pm 24$ & & & & & \\
\hline P3-101 & $0.704548 \pm 30$ & $0.512813 \pm 20$ & & & & 1.33 & \\
\hline P3-115 & $0.704539 \pm 20$ & $0.512777 \pm 22$ & Dredge 2 & & & & \\
\hline $2-1 *$ & $0.704466 \pm 39$ & $0.512824 \pm 29$ & 19.098 & 15.587 & 38.876 & & 3.79 \\
\hline $2-104$ & $0.702839 \pm 36$ & $0.513086 \pm 29$ & & & & & \\
\hline Sed1 & $0.709041 \pm 48$ & $0.512486 \pm 21$ & 18.732 & 15.609 & 38.596 & 0.82 & 6.44 \\
\hline Sed2 & $0.707143 \pm 41$ & $0.512532 \pm 24$ & $\begin{array}{l}\text { 18.771 } \\
\text { Teahitia }\end{array}$ & 15.615 & 38.690 & 0.99 & 22.9 \\
\hline $3-1 *$ & $0.704640 \pm 40$ & $0.512713 \pm 30$ & 19.128 & 15.594 & 38.890 & & 3.39 \\
\hline $3-3 *$ & $0.704547 \pm 39$ & $0.512785 \pm 20$ & 19.037 & 15.589 & 38.809 & & \\
\hline $3-5$ & $0.704836 \pm 43$ & $0.512767 \pm 20$ & 19.108 & 15.612 & 39.032 & 1.44 & 4.03 \\
\hline $3-7$ & $0.705024 \pm 48$ & $0.512762 \pm 24$ & & & & & \\
\hline $3-8$ & $0.704575 \pm 41$ & $0.512806 \pm 24$ & & & & & bet \\
\hline $3-100$ & $0.704508 \pm 34$ & $0.512782 \pm 23$ & & & & Lap & 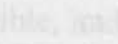 \\
\hline $3-101$ & $0.704624 \pm 26$ & $0.512779 \pm 22$ & & & & $\sqrt{4}=12$ & 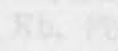 \\
\hline $3-113$ & $0.704691 \pm 43$ & $0.512740 \pm 22$ & & & & thes & 6 (nit a 2 \\
\hline $5-1$ & $0.704559 \pm 43$ & $0.512760 \pm 19$ & & & & & \\
\hline $5-5$ & $0.704659 \pm 53$ & $0.512791 \pm 21$ & & & & & \\
\hline $9-1$ & $0.705506 \pm 50$ & $0.512707 \pm 20$ & 19.117 & 15.624 & 38.983 & 1.83 & 5.30 \\
\hline $9-3$ & $0.704395 \pm 50$ & $0.512796 \pm 20$ & & & & & 3.42 \\
\hline $9-1 C D$ & $0.704577 \pm 36$ & $0.512747 \pm 20$ & & & & & \\
\hline $9-2 \mathrm{CD}$ & $0.704707 \pm 31$ & $0.512785 \pm 20$ & & & $\cos ^{2}$ & 20 & 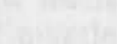 \\
\hline $\begin{array}{l}20-1 \\
22-1\end{array}$ & $\begin{array}{l}0.704590 \pm 38 \\
0.705006 \pm 42\end{array}$ & $\begin{array}{l}0.512774 \pm 21 \\
0.512713 \pm 19\end{array}$ & & & & & 4.72 \\
\hline $22-1$ & & & Rocard & & & & \\
\hline P4-3* & $0.705870 \pm 42$ & $0.512651 \pm 20$ & 19.221 & 15.649 & 39.136 & & 19.0 \\
\hline $4-2 *$ & $0.706017 \pm 41$ & $0.512582 \pm 31$ & 19.212 & 15.643 & 39.107 & & 16.6 \\
\hline $4-3$ & $0.706018 \pm 40$ & $0.512612 \pm 22$ & & & 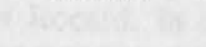 & & \\
\hline $4-8$ & $0.705886 \pm 38$ & $0.512658 \pm 21$ & & & $x_{0}$ & & \\
\hline $4-113$ & $0.705965 \pm 24$ & $0.512656 \pm 22$ & & te & $\sqrt{1}=$ & 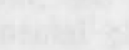 & \\
\hline $4-115$ & $0.705839 \pm 41$ & $0.512632 \pm 18$ & & & 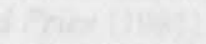 & & \\
\hline $4-123$ & $0.704806 \pm 47$ & $0.512761 \pm 20$ & & & $x^{2}+$ & & \\
\hline $4-124$ & $0.705981 \pm 46$ & $0.512610 \pm 23$ & & & 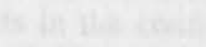 & 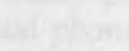 & \\
\hline \multirow{2}{*}{$34-1$} & $\begin{array}{l}0.705929 \pm 39 \\
0.705073 \pm 27\end{array}$ & $\begin{array}{l}0.512607 \pm 23 \\
0.512723 \pm 20\end{array}$ & & & & 1.74 & 4.77 \\
\hline & $0.705073 \pm 27$ & $0.512723 \pm 20$ & Moua Pihaa & & & & \\
\hline $28-1$ & $0.703798 \pm 33$ & $\begin{array}{l}0.512931 \pm 23 \\
0.512971 \pm 20\end{array}$ & 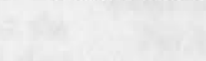 & & a & & \\
\hline $28-1 C D$ & $0.703642 \pm 25$ & $0.512971 \pm 20$ & 19.222 & 15.540 & & 1.8 & \\
\hline $\begin{array}{l}29-1 \\
29-2 \mathrm{CD}\end{array}$ & $\begin{array}{l}0.703709 \pm 27 \\
0.703605 \pm 36\end{array}$ & $\begin{array}{l}0.512932 \pm 20 \\
0.512985 \pm 20\end{array}$ & 19.222 & 10.040 & 38.744 & 1.0 & $\begin{array}{l}4.06 \\
5.69\end{array}$ \\
\hline & & & Cyana & & & & \\
\hline $81-3$ & $0.704504 \pm 37$ & $0.512888 \pm 60$ & $\begin{array}{l}18.993 \\
\text { Standards }\end{array}$ & 15.563 & 38.681 & & 8.35 \\
\hline E\&A & 0.708033 & 0.512608 & & & & & \\
\hline $\begin{array}{l}\text { BCR-1 } \\
\text { NBS } 983\end{array}$ & & 0.512008 & 16.925 & 15.473 & 36.659 & & \\
\hline
\end{tabular}

Errors are $2 \sigma$ analytical errors on the last quoted decimals. See text for analytical details.

* indicates $\mathrm{Pb}$ isotopic ratios and concentration by $\mathrm{P}$. Vidal, Université Clermont Ferrand II.

correlation (not shown) of $\log (\mathrm{Cr})$ with $\log (\mathrm{Ni})$ with a slope of $\approx 1$, suggests that their bulk partition coefficients are nearly equal. Only $1-2 \%$ of disseminated chromite within the precipitated olivine (modal chromite abundance $<1 \%$ ) would therefore account for the observed $\mathrm{Ni}-\mathrm{Cr}$ relationships. The effects on the major and other trace elements of such small amounts of chromite fractionation would be minimal.

Major element modelling [Wright and Doherty, 1970] of the major element variations in the Teahitia and Mehetia 


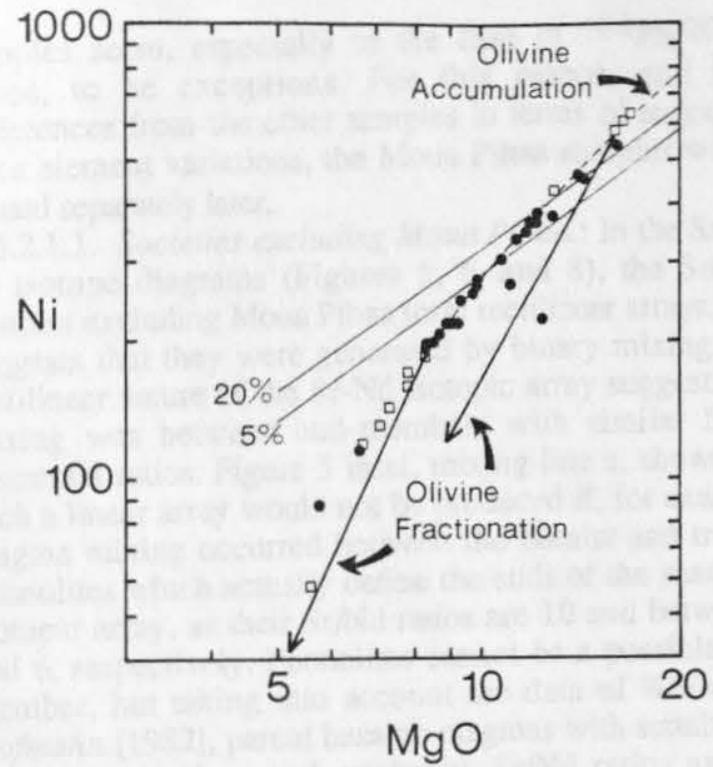

Fig. 7. $\log (\mathrm{Ni})$ versus $\log (\mathrm{MgO})$ for Teahitia and Mehetia basic samples. Symbols as in Figure 2. Mantle melting lines for 5 and $20 \%$ partial melting, and the olivine fractionation and accumulation lines are from or based on Hart and Davis [1978].

sample groups, represented by P3-101 (basic) and P3-3 (evolved) for Mehetia and 9-3 (basic) and 3-5 (evolved) for Teahitia, yields calculated fractionating assemblages containing $77 \%$ olivine: $23 \%$ clinopyroxene and $82 \%$ olivine: $18 \%$ clinopyroxene respectively. From the least squares calculations, consistent values of $F \approx 0.7$ (the fraction of original liquid remaining) are obtained in both cases. Modelling of the incompatible element variations using a Rayleigh distillation law, assuming perfect incompatibility of the elements $\mathrm{Ti}, \mathrm{P}, \mathrm{K}, \mathrm{Na}, \mathrm{Rb}, \mathrm{Zr}, \mathrm{Nb}$, REE, and taking the P3-101 elemental concentrations as those of the parent and the P3-3 concentrations as the daughter values, again gives $F$ values of $\approx 0.7$ for Mehetia. An identical result is obtained between the two Teahitia end-members 9-3 and 3-5. Interestingly, the $\mathrm{Al}$ variations give similar $F$ values, suggesting that $\mathrm{Al}$ is behaving incompatibly in these lavas. This is in agreement with the petrographic evidence and the lack of Eu anomalies in the basaltic REE patterns (Figure 3 ) which both suggest that plagioclase phenocrysts are not fractionating from these basalts.

5.1.2. Trachy-phonolites. The question of whether the trachy-phonolites can be derived from basaltic parents by fractionation is difficult to answer and yet is important because of the distinctive isotopic compositions of most of these evolved rocks. We need to assess whether they are isotopically distinct because they have interacted during differentiation with isotopically distinct reservoirs such as metasomatised sections of the mantle, altered oceanic crust, sediments, etc., or because they represent unique samples of an otherwise untapped magma source.

Least squares major element models are poorly constrained because of the number of fractionating phases which could possibly be involved. The significance of Rayleigh distillation modelling of trace element differences is also difficult to assess as it is possible that no element is truly incompatible. Apatite fractionation may affect the REE [e.g., Nagasawa and Schnetzler, 1971; Irving, 1978], while extensive clinopyroxene fractionation will affect Y and to a lesser extent $\mathrm{Zr}$ [e.g., Dunn and McCallum, 1982; Watson and Ryerson, 1986]. We can however say something about the minimum amount of fractionation which would be needed to pass from a basalt to a trachyphonolite. Using $\left(C_{\mathrm{TRACH}}-C_{\mathrm{BAS}}\right) / C_{\mathrm{BAS}}$ as a measure of the relative elemental enrichment factors $\left(C_{\mathrm{TRACH}}\right.$ and

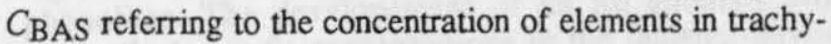
phonolites and basalts, respectively), and using the concentrations of elements in 3-5 for $C_{\mathrm{BAS}}$ and 4-8 (one member of the less silicic trachy-phonolite group) for $C_{\text {TRACH }}$ shows $\mathrm{K}_{2} \mathrm{O}, \mathrm{Rb}, \mathrm{Zr}$, and $\mathrm{Pb}$ to have by far the highest enrichments, varying from $1.7(\mathrm{Zr})$ to $2.3(\mathrm{~Pb})$. $\mathrm{K}_{2} \mathrm{O}$ and $\mathrm{Rb}$ have comparable enrichments of 2.00 and 2.06. These highest enrichment values should indicate the most incompatible elements, and give a minimum $F$ value, again assuming complete incompatibility, of 0.33 . Although the small Eu anomalies $\left(\mathrm{Eu} / \mathrm{Eu}^{*}=0.96\right)$ in the less silicic trachy-phonolites suggest that they have not fractionated large amounts of feldspar, some effect of Kfeldspar on $\mathrm{K}, \mathrm{Rb}$, and $\mathrm{Pb}$ concentrations is possible, and so we stress $F=0.33$ derived from the $\mathrm{K}, \mathrm{Rb}, \mathrm{Pb}$ enrichments is a minimum estimate of the amount of fractionation that has occurred.

Although no firm evidence that the trachy-phonolites are derived by fractionation from a more basic parent can be given, the other possibility, that they are partial melts of the mantle, is no better substantiated. Phonolitic melts which are thought to have last equilibrated at mantle pressures are reported from various continental localities [see Irving and Price, 1981, and references therein). The supposedly mantle-derived phonolites from Bokkos, Nigeria [Irving and Price, 1981] have REE curves very similar to those from Rocard. In major element terms, however, they are somewhat different, the Nigerian phonolites (and indeed all the continental phonolites reported by Irving and Price [1981] being distinctly more sodic, and less potassic than the Rocard trachy-phonolites. $\mathrm{Ni}, \mathrm{Cr}$, and $\mathrm{V}$ contents in the continental phonolites (8$310,11.8-429$, and $16-83 \mathrm{ppm}$, respectively) are all distinctly higher than in Rocard, where they are below detection limits ( $<10 \mathrm{ppm}$ in all cases).

No basaltic samples with isotopic compositions similar to the trachy-phonolites which could serve as parental magmas have yet been found on the seamouts. White and Hofmann [1982], however, show basalt samples from Tahaa and Huahine (north-west of Tahiti) whose compositions bracket the Rocard field, indicating that basalt isotopically similar to the trachy-phonolites exist in the Societies. The evolved sample from Cyana (81 -3) supports the view that the evolved rocks are not all isotopically distinct from the basalts. This sample has isotopic ratios of $\mathrm{Sr}$ and $\mathrm{Nd}$ which fall within the range for Teahitia and Mehetia basalts but $\mathrm{SiO}_{2}$ slightly higher than the Rocard trachy-phonolites.

\subsection{Petrogenesis}

5.2.1.Sources and end-members. While most of the Society seamount samples seem to form well-defined trends on the isotopic diagrams (Figures 5 and 6) the Moua Pihaa 
samples seem, especially in the case of $206 \mathrm{~Pb} / 204 \mathrm{~Pb}$ ratios, to be exceptions. For this reason, and their differences from the other samples in terms of major and trace element variations, the Moua Pihaa samples will be treated separately later.

5.2.1.1. Societies excluding Moua Pihaa.: In the Sr-Nd$\mathrm{Pb}$ isotope diagrams (Figures 5, 6, and 8), the Society samples excluding Moua Pihaa form rectilinear arrays. This suggests that they were generated by binary mixing. The rectilinear nature of the $\mathrm{Sr}-\mathrm{Nd}$ isotopic array suggests that mixing was between end-members with similar $\mathrm{Sr} / \mathrm{Nd}$ elemental ratios. Figure 5 inset, mixing line a, shows that such a linear array would not be produced if, for example, magma mixing occurred between the basalts and trachyphonolites which actually define the ends of the seamount isotopic array, as their $\mathrm{Sr} / \mathrm{Nd}$ ratios are 10 and between 1 and 6, respectively. Phonolites cannot be a possible endmember, but taking into account the data of White and Hofmann [1982], parent basaltic magmas with suitable Sr$\mathrm{Nd}$ isotopic values and, probably, $\mathrm{Sr} / \mathrm{Nd}$ ratios exist to generate this array.

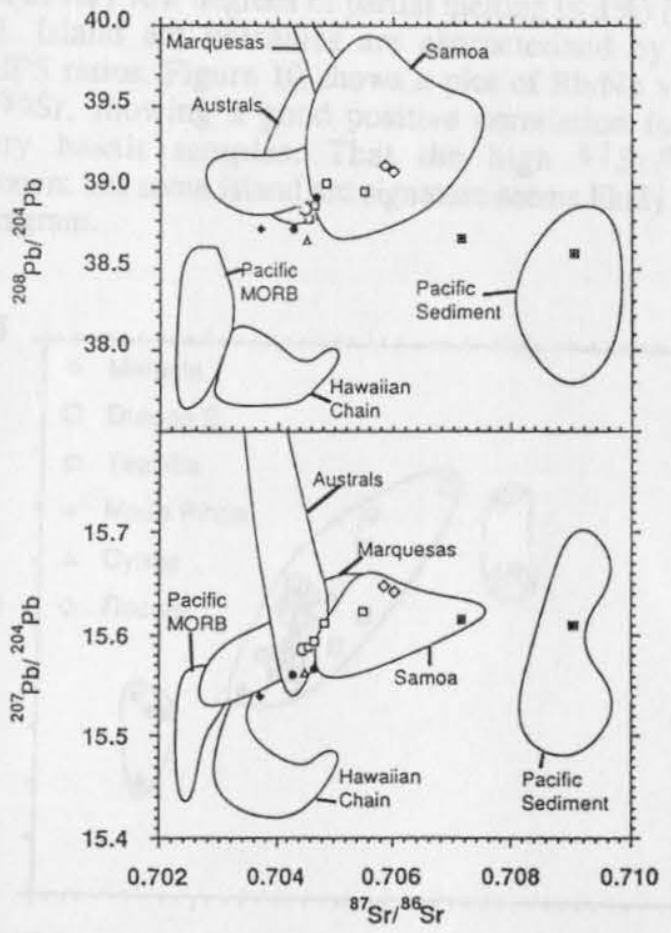

Fig. 8. The ${ }^{207} \mathrm{~Pb} / 204 \mathrm{~Pb}$ and $208 \mathrm{~Pb} / 204 \mathrm{~Pb}$ versus ${ }^{87} \mathrm{Sr} / 86 \mathrm{Sr}$ for Pacific MORB and sediments, and various oceanic islands. Data references as for Figures 5 and 6 . Society sediment samples SED1 and 2 (Table 3) are shown as crossed squares.

Another process which may account for the observed isotopic patterns is contamination of the magmas by ocean floor sediment during their ascent through the oceanic crust. The fact that the local sediments generally do not lie on plausible mixing lines through the basalt array seems to argue against this possibility.

It seems therefore that the isotopic arrays must either result from mixing between two different basic magmas with similar $\mathrm{Sr} / \mathrm{Nd}$ values derived from two end-member sources or reflect a variability already present in a heterogeneous source. For two reasons, we prefer the latter hypothesis. First, decreasing the $\mathrm{Sr} / \mathrm{Nd}$ ratio from 10 in the basalts to 6 in the least differentiated trachy-phonolites by $70 \%$ fractional crystallization (see above) would require a minimum $D_{\mathrm{Sr}}$ value of about 0.6 . Such a value requires a substantial proportion $(\approx 30 \%)$ of plagioclase in the cumulate which is untenable considering the absence of a significant Eu anomaly in at least the Si-poor trachyphonolites. The developement of an Eu anomaly and markedly lower Sr concentrations in the feldspar-phyric silicic trachy-phonolites suggests that if feldspar fractionation had altered the $\mathrm{Sr} / \mathrm{Nd}$ ratio in the less silicic trachy-phonolites, we might expect to see an Eu anomaly. We prefer the idea that $\mathrm{Sr}$ and $\mathrm{Nd}$ are present in the source in similar proportions in each end-member and were fractionated by the melting process as a result of variable source mineralogy and/or degree of melting. Second, because a range of isotopic compositions is seen on each volcano but no single volcano shows the whole range of isotopic ratios, it seems unlikely that two end-member basalts are mixing within each volcano.

Figure 9 shows that the high ${ }^{87} \mathrm{Sr} / 86 \mathrm{Sr}$ end-member has high $\mathrm{SiO}_{2}$ (considering either the basalts only, or taking the trachy-phonolites into consideration as well). There would appear to be several ways of changing the $\mathrm{SiO}_{2}$ content of a magma:

First, olivine fractionation will increase the $\mathrm{SiO}_{2}$. Absence of any significant correlation between $\mathrm{Mg \#}$ and ${ }^{87} \mathrm{Sr} / 86 \mathrm{Sr}$ (not shown) implies that fractionation alone was not responsible for the $\mathrm{SiO}_{2}$ increase. In addition, the modelled fractionation assemblage of $80 \%$ olivine and $20 \%$ clinopyroxene has a bulk $\mathrm{SiO}_{2}$ of approximately $42.5 \%$, similar to that of the magmas. Fractionation of such an assemblage will not greatly affect the $\mathrm{SiO}_{2}$ of the magmas.

Increasing the degree of partial melting in the range 0 $20 \%$ in a mantle source will also lead to an increase in the $\mathrm{SiO}_{2}$ content and Si-saturation of a magma [Green and Ringwood, 1967; Jaques and Green, 1980] (see Thompson

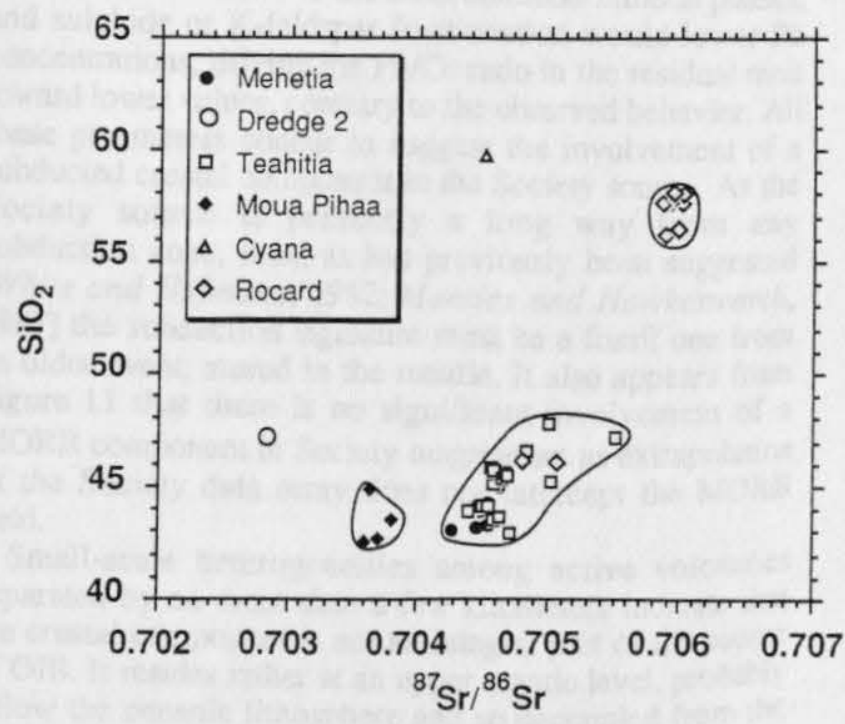

Fig. 9. The $\mathrm{SiO}_{2}$ versus $87 \mathrm{Sr} / 86 \mathrm{Sr}$ for Society Seamount samples. Note the positive correlation for the basaltic samples when Moua Pihaa data excluded. 
[1987] for a review). This effect, however, seems unlikely to have been reponsible for the chemical changes observed in the Societies because if varying degrees of partial melting alone were controlling the $\mathrm{SiO}_{2}$ changes, then at small degrees of partial melting $(<2 \%)$ we might expect to see some correlation between $\mathrm{SiO}_{2}$ and a more to less incompatible element ratio. For example, the slope of the REE diagram might be expected to decrease with increasing $\mathrm{SiO}_{2}$. We find, however, no significant correlation between $\mathrm{SiO}_{2}$ and $\mathrm{Ce} / \mathrm{Yb}$ implies that this does not infact occur.

$\mathrm{SiO}_{2}$ contents in mantle-derived magmas can also be affected by altering the volatile composition and concentration in the source. This is the effect thought to be responsible for the $\mathrm{SiO}_{2}$-rich nature of island arc magmas [Kushiro, 1969; Nicholls and Ringwood, 1973].

The processes responsible for producing island arc magmas are also capable of fractionating large ion lithophile (LIL) (i.e., Rb, Ba, K, Sr, Th) from high field strength (HFS) (i.e., $\mathrm{Nb}, \mathrm{Ta}$ ) elements [Nicholls and Ringwood, 1973; Perfit et al., 1980; Palacz and Saunders, 1986]. These two groups of elements should not generally be fractionated from one another by magmatic processes, except at very low degrees of partial melting $(\leq 1 \%)$ [Gast, 1968]. Island arc volcanics are characterized by high LIL/HFS ratios. Figure 10 shows a plot of $\mathrm{Rb} / \mathrm{Nb}$ versus ${ }^{87} \mathrm{Sr} / 86 \mathrm{Sr}$, showing a good positive correlation for the Society basalt samples. That the high ${ }^{87} \mathrm{Sr} / 86 \mathrm{~S} \mathrm{r}$ component has some island arc signature seems likely from this diagram.

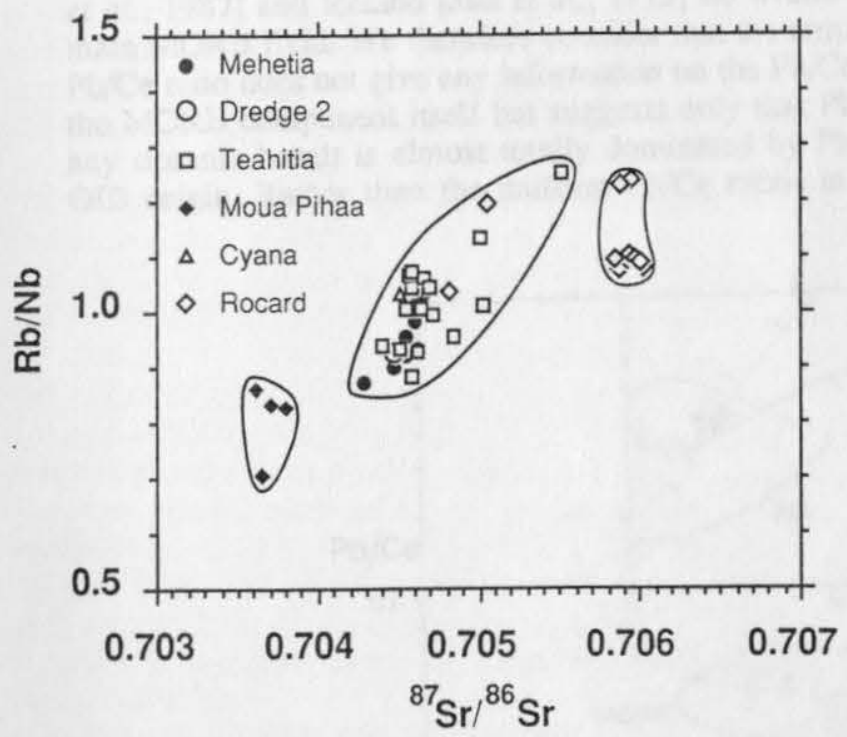

Fig. 10. The $\mathrm{Rb} / \mathrm{Nb}$ versus ${ }^{87} \mathrm{Sr} / 86 \mathrm{Sr}$ for the Society Seamounts samples. Note the good positive correlation between these parameters for the basaltic samples excluding Moua Pihaa.

Similar $\mathrm{Nb} / \mathrm{U}$ and $\mathrm{Pb} / \mathrm{Ce}$ (or $\mathrm{Ce} / \mathrm{Pb}$ ) ratios in $\mathrm{OIB}$ and MORB have been suggested to be a result of an identical geochemical behavior during partial melting or crystal fractionation processes [Hofmann et al., 1986]. This implies that $\mathrm{Pb} / \mathrm{Ce}$ variations could be used to determine addition of continental or primitive components to oceanic magmas. Figure 11 shows a good correlation between

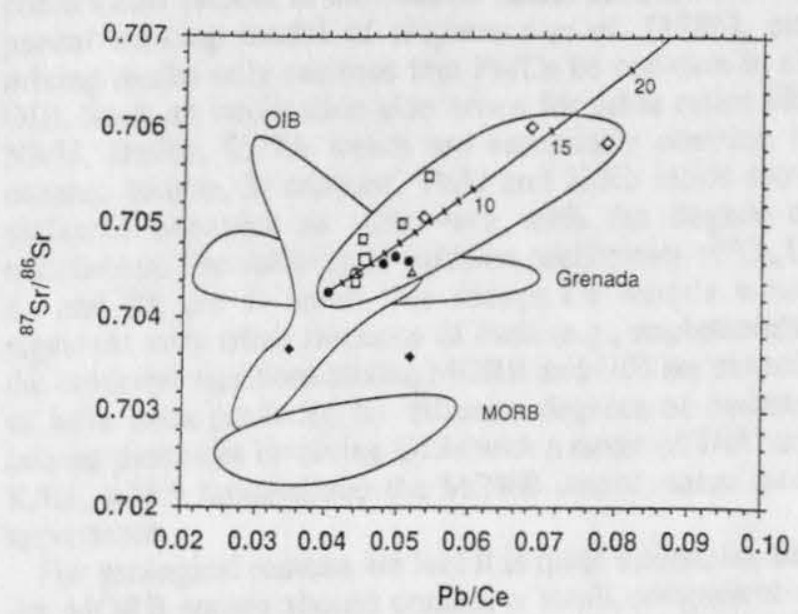

Fig.11. The ${ }^{87} \mathrm{Sr} /{ }^{86} \mathrm{Sr}$ versus $\mathrm{Pb} / \mathrm{Ce}$ for the Society Seamounts samples, plus one sample from Tahaa island (open square symbol (K.P. Jochum, personal communication, 1989). Fields for MORB [Hofmann et al., 1986] and Grenada [Thirlwall and Graham, 1984] also shown. The mixing line is between Mehetia sample P3-4 and average terrigenous sediment of Ben Othman et al. [1989] taking ${ }^{87} \mathrm{Sr} / 86 \mathrm{Sr}$ of 0.74 for the latter. The filled square represents sample 73-185 from the island of Tahaa.(K.P. Jochum, personal communication, 1989).

${ }^{87} \mathrm{Sr} / 86 \mathrm{Sr}$ and $\mathrm{Pb} / \mathrm{Ce}$ in the Society samples. The enriched end-member is therefore characterized not only by high $\mathrm{Rb} / \mathrm{Nb}, \mathrm{SiO}_{2}$, and $\mathrm{Sr}$ isotopic ratios but also by high $\mathrm{Pb} / \mathrm{Ce}$ ratios. The latter feature has been emphasized to be a characteristic of the continental crust by Hofmann et al. [1986]. Also shown is a mixing line that passes through these samples constructed using sample P3-4 as the Society end-member and the average terrigenous sediment from Ben Othman et al. [1989] $(\mathrm{Pb}=23.2, \mathrm{Ce}=77.9, \mathrm{Sr}$ $=233 \mathrm{ppm})$ with an elevated ${ }^{87} \mathrm{Sr} / 86 \mathrm{Sr}$ of 0.74 . The higher $\mathrm{Pb} / \mathrm{Ce}$ in the Rocard acidic magmas cannot be a result of magmatic processes: both elements are equally incompatible relative to the most common mineral phases, and sulphide or $\mathrm{K}$-feldspar fractionation would lower $\mathrm{Pb}$ concentrations, driving the $\mathrm{Pb} / \mathrm{Ce}$ ratio in the residual melt toward lower values, contrary to the observed behavior. All these parameters concur to suggest the involvement of a subducted crustal component in the Society source. As the Society source is presently a long way from any subduction zone, then, as has previously been suggested [White and Hofmann, 1982; Menzies and Hawkesworth, 1987] the subduction signature must be a fossil one from an older event, stored in the mantle. It also appears from Figure 11 that there is no significant involvement of a MORB component in Society magmatism as extrapolation of the Society data array does not intercept the MORB field.

Small-scale heterogeneities among active volcanoes separated by no more than a few kilometers indicate that the crustal component is not an integral part of the source of OIB. It resides rather at an upper mantle level, probably below the oceanic lithosphere and so decoupled from the moving plate, where it is sampled by an ascending mantle plume. The distribution of this crustal component is probably approximately delineated by the extent of the Pacific Superswell, the surface expression of a stationary thermal anomaly beneath the Pacific Plate [ $\mathrm{MCN}$ utt and 
Fischer, 1987]. The Superswell thermal anomaly has been presumably present in the Pacific since the Early Cretaceous [Smith et al., 1989].

We suggest that the nature of $\mathrm{Pb} / \mathrm{Ce}$ components in Society basalts may be further discussed if, contrary to Hofmann et al. [1986], we do not make the a priori that $\mathrm{MORB}$ and OIB end-members have identical $\mathrm{Pb} / \mathrm{Ce}$ ratios. Anderson [1982] suggested that MORB are depleted magmas slightly contaminated by OIB melts, whereas we prefer a slightly different, although admittedly difficult to document, situation of a MORB source invaded by tiny amounts of OIB. Figure 12 shows the $\mathrm{Pb} / \mathrm{Ce}$ versus $\mathrm{Pb}$ data from Hofmann et al. [1986] together with our Society data and some mixing hyperbolae. The mixing lines assume that each component has uniform $\mathrm{Pb} / \mathrm{Ce}$ ratios. They have been drawn between the most $\mathrm{Pb}$-rich OIB, using an average OIB $\mathrm{Pb} / \mathrm{Ce}$ of 0.04 , and MORB sources with different but arbitrary $\mathrm{Pb} / \mathrm{Ce}$ ratios $(\mathrm{Pb}$ content of MORB source taken as $0.04 \mathrm{ppm}$, i.e., the source which would produce the most primitive MORB magmas by $20 \%$ partial melting). The mixing lines show that because of the enormously higher $\mathrm{Pb}$ contents of OIB magmas, addition of between 1 and 3\% OIB melt to any MORB source buffers the $\mathrm{Pb} / \mathrm{Ce}$ ratio of the mixture almost completely. Such mixing hypotheses are not at variance with $\mathrm{Pb}$ isotope evidence since, with the exception of a few hotspots usually either from the Dupal or HiMu clans, the $206 \mathrm{~Pb} / 204 \mathrm{~Pb}$ fields for MORB and OIB [e.g., Figure 9 of Zindler and Hart [1986] and White et al. [1987] overlap significantly. For instance most $\mathrm{Pb}$ isotope data from Hawaii [Tatsumoto, 1978; Stille et al., 1983; Tatsumoto et al., 1987] and Iceland [Sun et al., 1975] lie within the main MORB field. We therefore consider that the erupted $\mathrm{Pb} / \mathrm{Ce}$ ratio does not give any information on the $\mathrm{Pb} / \mathrm{Ce}$ of the MORB component itself but suggests only that $\mathrm{Pb}$ in any oceanic basalt is almost totally dominated by $\mathrm{Pb}$ of OIB origin. Rather than the uniform $\mathrm{Pb} / \mathrm{Ce}$ ratios in all components present in the oceanic basalt advocated in the partial melting model of Hofmann et al. [1986], our mixing model only requires that $\mathrm{Pb} / \mathrm{Ce}$ be constant in all OIB. Such an implication also arises for other ratios like $\mathrm{Nb} / \mathrm{U}, \mathrm{Ba} / \mathrm{Rb}, \mathrm{Cs} / \mathrm{Rb}$ which are essentially constant in oceanic basalts. In contrast, $\mathrm{Th} / \mathrm{U}$ and $\mathrm{K} / \mathrm{Rb}$ ratios show different behavior as they vary with the degree of enrichment. The solid/liquid partition coefficients of Th, U, $\mathrm{K}$, and $\mathrm{Rb}$ are so small that except for liquids which represent very small fractions of melt (e.g., nephelinites), the observed variations among MORB and OIB are unlikely to have been produced by different degrees of melting: mixing processes involving OIBs with a range of $\mathrm{Th} / \mathrm{U}$ and $\mathrm{K} / \mathrm{Rb}$, which contaminate the MORB source, seem more appropriate.

For geological reasons we feel it is quite reasonable that the MORB source should contain a small component of OIB "contaminant". At the present day, an estimated $10 \%$ of the Earth's present oceanic crust, which is on average 60 $\mathrm{Ma}$, is covered by oceanic plateaux ostensibly of hotspot origin [Ben Avraham et al., 1981]. This suggests that most of the upper mantle has potentially been influenced by ascending plume material at some time in the last few billion years, although not to the extent that the dominant LREE-depleted signature of MORB has been lost.

Figure 12 can also be used to constrain how much average sediment probably contributes to the Society magmatism. For this estimation, however, the trachphonolite samples must first be excluded, as their extreme fractionation stage has been shown to have at least doubled their $\mathrm{Pb}$ contents when compared to the most evolved basalts. Using therefore only the Society Seamount basalt data on Figure 12 and average terrigenous compositions from Ben Othman et al. [1989] implies between 5 and 10\% more sediment in the most contaminated basalts than the least contaminated ones. The position of sample 185 from Tahaa (analysis by K.P. Jochum, personal communication,

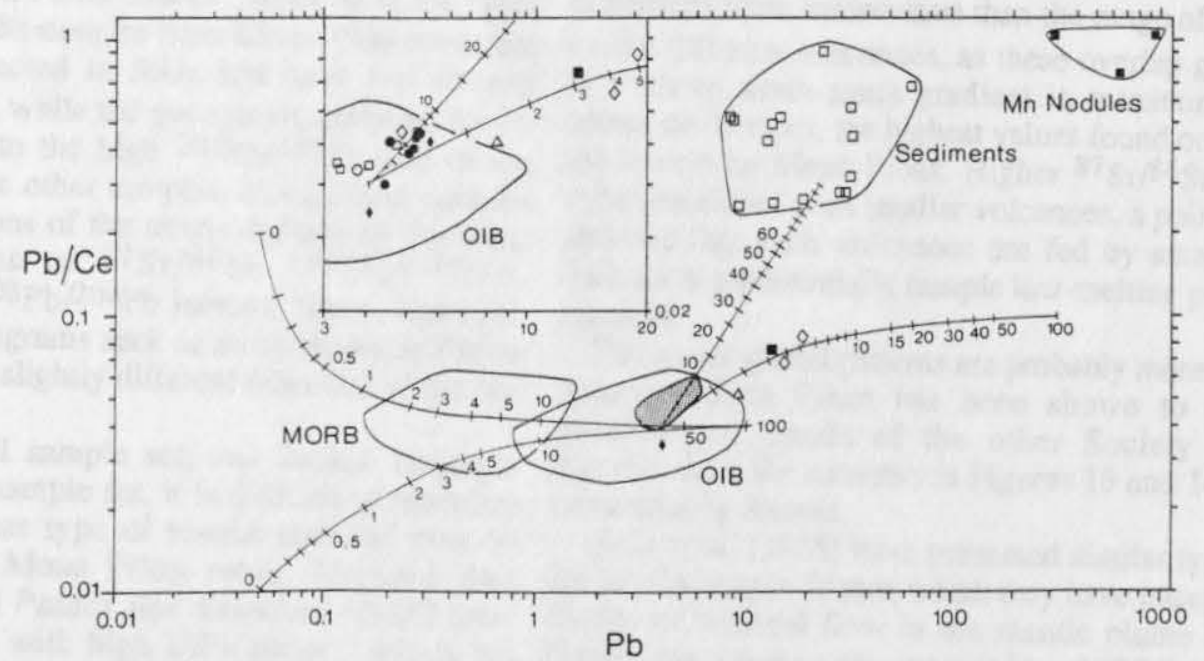

Fig. 12. $\log (\mathrm{Pb} / \mathrm{Ce})$ versus $\log (\mathrm{Pb})$ for published MORB and OIB data [Hofmann et al., 1986], recently published sediment data [Ben Othman et al., 1989], and data from the present study. Inset is an enlargement of the Society data field shown stippled on the main diagram. Mixing lines are shown between a supposed OIB endmember $(\mathrm{Pb}=10 \mathrm{ppm}, \mathrm{Pb} / \mathrm{Ce}=0.04)$ and two possible MORB end-members, both with $\mathrm{Pb}=0.04 \mathrm{ppm}$ but with $\mathrm{Pb} / \mathrm{Ce}$ of 0.01 and 0.2 . Also shown are mixing lines between an average unradiogenic Society seamount basalt $(\mathrm{Pb}=4 \mathrm{ppm}, \mathrm{Pb} / \mathrm{Ce}=0.04)$ and average terrigenous sediment [Ben Othman et al., 1989], and between the same seamount basalt and a component at $\mathrm{Pb}=350 \mathrm{ppm}, \mathrm{Pb} / \mathrm{Ce}=0.08$. Graduations on the mixing lines show the percentage of OIB or sediment in the mixture. 
1989) on the $\mathrm{Pb} / \mathrm{Ce}$ plot is more difficult to explain. Any mixing line passing through both 185 and the seamount basalt data would point toward an end-member with high $\mathrm{Pb}(100-1000 \mathrm{ppm})$ and low $\mathrm{Pb} / \mathrm{Ce}(0.08-0.1)$. No geological material at present analyzed falls into this region of the diagram. We are left to conclude that either 185 is mixing toward a different end-member or its $\mathrm{Pb}$ has been anomalously enriched by magmatic processes.

The general conclusions from the Society $\mathrm{Pb} / \mathrm{Ce}$ systematics turn out to be quite consistent with the inferences drawn from the isotopic data: if one excludes Moua Pihaa, the hotspot magmas are dominated by two sources, one being a primary OIB component, the other being recycled continental material. MORB-type asthenospheric or lithospheric material does not seem to contribute significantly to the formation of these magmas.

The above observations on subduction effects in the Society source are very similar to those made by Palacz and Saunders [1986] on the Cook-Austral-Samoa (CAS) chain. Where the Societies seem to differ from the CAS is in the behavior of $\mathrm{Pb}$. Palacz and Saunders show a poor negative correlation between ${ }^{87} \mathrm{Sr} / 86 \mathrm{Sr}$ and ${ }^{206} \mathrm{~Pb} / 204 \mathrm{~Pb}$ in the CAS. Their data together with other published data are given in Figure 8, where the negative correlation is clearly seen. As Palacz and Saunders attributed the variations in ${ }^{87} \mathrm{Sr} / 86 \mathrm{Sr}$ to old enrichments of $\mathrm{Rb} / \mathrm{Sr}$, they took the negative $\mathrm{Pb}-\mathrm{Sr}$ isotope correlation to imply that $\mathrm{U} / \mathrm{Pb}$ was depleted in the same event. We have already seen that the Societies show a good positive correlation between ${ }^{87} \mathrm{Sr} / 86 \mathrm{Sr}$ and $\mathrm{Pb}$ isotopes (Figure 8). Most important of these correlations is that between ${ }^{87} \mathrm{Sr} / 86 \mathrm{Sr}$ and $207 \mathrm{~Pb} / 204 \mathrm{~Pb}$. As the latter ratio is almost constant at the present day and has been so for the last billion years (due to the relatively small decay constant of $235 \mathrm{U}$ ), these correlations imply that the radiogenic subducted component is old. Whether this age is the subduction age or the age of the craton from which the subducted sediments were derived seems impossible to tell.

5.2.1.2. The Moua Pihaa source.: Relative to the other seamount samples, the samples from Moua Pihaa are richer han might be expected in $\mathrm{SiO}_{2}$ and have less steeply sloping REE curves, while the one sample analyzed for $\mathrm{Pb}$ sotope ratios falls to the high $206 \mathrm{~Pb} / 204 \mathrm{~Pb}$ side of the arrays defined by the other samples. Moua Pihaa samples ie along continuations of the trends defined by the other eamounts in terms of ${ }^{87} \mathrm{Sr} / 86 \mathrm{Sr}, 143 \mathrm{Nd} / 144 \mathrm{Nd}$, $207 \mathrm{~Pb} / 204 \mathrm{~Pb}$, and $208 \mathrm{~Pb} / 204 \mathrm{~Pb}$ isotopic ratios, however. it is evident from diagrams such as those shown in Figure 5 that their source is slightly different from that of the rest f the Societies.

With such a small sample set, and limited chemical yariation within the sample set, it is difficult to speculate nuch further on what type of source material may be esponsible for the Moua Pihaa rocks. Michard and 1lbarède [1985] and Palacz and Saunders [1986] have uggested that rocks with high $\mathrm{U} / \mathrm{Pb}$ ratios - which the Moua Pihaa source may be if the U enrichment was recent nough ( $<1 \mathrm{Ga}$ ) to produce negligible $207 \mathrm{~Pb}$ effects- could epresent the traces of subducted hydrothermally-altered ceanic crust in their source. In the case of the Australs alacz and Saunders [1986] thought such subducted crust nay have given the lavas relatively depleted incompatible lement ratios. The distinctly shallower REE patterns of
Moua Pihaa lavas could be a manifestation of this same effect.

\section{SPATIAL CHEMICAL VARIATIONS}

Combining the chemical information and the topographic features of the Society Seamounts allows us to look at geographical variations in lava composition across the hotspot. Figures 13 and 14 show all the topographic features, together with contours for the maximum $\mathrm{SiO}_{2}$ and ${ }^{87} \mathrm{Sr} / 86 \mathrm{Sr}$ values so far found on the volcanoes. Such maps are, of course, subject to the effects of sampling bias, and with dredged samples there is no information on how representative the sampling is.

Figure 13 shows that high-silica lavas are found in the center of the Society bulge. More precisely, the $\mathrm{SiO}_{2}$ contours are strongly controlled by the evolved Rocard and Cyana samples. In view of the evidence from many ocean islands that evolved, alkaline magmas are normally produced during the late stages of volcanic activity (the late stage phonolite plugs on Tahiti [Brousse et al., 1985] are an example) and that they are often found in the central caldera-collapse structures on the islands, it is interesting that these two, centrally located, quite large, seismically active volcanoes should be the only ones so far found with evolved rocks on them. It may suggest that the magma supply rate to these volcanoes is lower than elsewhere, allowing the subvolcanic magma chambers enough time to stagnate and reach extreme fractionation stages. If this is the case, it obviously has important implications for the amount of melt being produced in different regions of the hotspot. More detailed sampling of all the volcanoes to determine accurately the distribution of evolved rock types is required, however, before this speculation can be usefully applied.

Maximum ${ }^{87} \mathrm{Sr} /{ }^{86} \mathrm{Sr}$ (Figure 14 ) was chosen as it shows the variations in the maximum contribution of the recycled continental material to the various volcanoes. This is perhaps more informative than the range of values found on the different volcanoes, as these overlap greatly. There is a strong north-south gradient in maximum ${ }^{87} \mathrm{Sr} / 86 \mathrm{Sr}$ across the hotspot, the highest values found on Rocard, and the lowest on Moua Pihaa. Higher ${ }^{87} \mathrm{Sr} / 86 \mathrm{Sr}$ ratios seem to be associated with smaller volcanoes, a point which may indicate that such volcanoes are fed by smaller material fluxes and preferentially sample low-melting point recycled material.

The actual spatial patterns are probably more complicated because Moua Pihaa has been shown to fall off the geochemical trends of the other Society seamounts. Nevertheless, the contours in Figures 13 and 14 are mostly controlled by Rocard.

Geist et al. [1988] have presented similar types of maps for the Galapagos Islands which they have interpreted as the results of toroidal flow in the mantle plume beneath the Galapagos, causing the surrounding MORB mantle to be stirred into the rising plume. This model implies some symmetrical distribution of isotopic values across the plume, something which is evidently not the case in the Societies, and a contribution of a depleted mantle source, which we have been able to exclude on geochemical grounds.

Overall, we suspect that the absence of any MORB 
influence in the Societies is linked to the limited interaction between the hotspot magmas and the lithosphere through which they pass on their way to the surface. This can be illustated by comparing the bathymetry and geochemistry of the Hawaiian and Society volcanoes. Unfortunately, although Hawaiian eruption rates are known quite well, there are no published estimates of eruption rate for the Societies. Comparison of the volume of the Hawaii Island edifice, which represents the last 0.5 m.y. of subaerial activity in the Hawaiian chain, and the Tahiti-Nui edifice, whose subaerial age range is $1.23-0.51$ Ma [Duncan and McDougall, 1976] gives some qualitative impression in the eruption rate differences. Thus the total volume of Hawaii down to the deep ocean floor is estimated as $113,000 \mathrm{~km}^{3}$ [Bargar and Jackson, 1974]. The estimate of the volume of Tahiti-Nui is $60,000 \mathrm{~km}^{3}$ [Williams, 1933]. Taking the age range of subaerial volcanism to be proportional to the total age of the volcano implies that the eruption rate is 2.7 times greater on Hawaii than it was on Tahiti-Nui.

In the Societies, the steep REE patterns suggest small degrees of partial melting, while the numerous distinct active edifices show that the melt follows a multitude of separate paths to the surface. As discussed earlier, the overall volume of the melts which build up the Society volcanoes is probably small. These factors combine to extract low melting point components preferentially from the Society source and bring them through the lithosphere without greatly reheating and remelting the latter. In Hawaii, on the other hand, the degree of partial melting is certainly higher, giving rise to large volumes of mainly tholeiitic magmas with only moderately enriched REE patterns. The production of huge sequential central volcanoes above fairly narrow mantle feeder zones leads to appreciable reheating and remelting of the MORB lithosphere.

The lack of oceanic lithosphere involvement in the Society magmas contrasts with their location within the Pacific bathymetric Superswell, a region of anomalously shallow seafloor covering some 15 million $\mathrm{km}^{2}$ in the west Pacific, which possesses a very thin elastic layer [Calmant and Cazenave, 1986]. The Superswell is thought to be shallow because the lithosphere and possibly also the asthenosphere are anomalously hot in this region [ $\mathrm{McNutt}$ and Fischer, 1987]. McNutt and Fischer [1987] observe that the Polynesian hotspots only appear to produce island chains once inside the margins of the Superswell but find that the Polynesian hotspots alone could not have provided the heat to generate the Superswell. They suggest that the Superswell lithosphere had been thermally thinned even before it encountered any hotspots and that because of this the relatively weak Polynesian hotspots with their small magma volumes, could easily burn through to produce ocean island volcanism in the Superswell region.

Several possible heat sources for the Superswell thermal anomaly have been considered. McNutt and Fischer [1987] ruled out the possibility that high radioactive element contents in the lithosphere could provide the heat required, as they found such radioactive concentrations incapable of producing a thermal anomaly of sufficient amplitude. A chemically passive lithosphere as found in our work, combined with the absence of any higher concentration of hotspot volcanism near the center of the Superswell seems to argue that a superplume is not the ultimate cause of the large bathymetric anomaly. The Superswell seems more likely to reflect an anomalously hot region in the asthenosphere. Indeed, the very nature of hotspots, and their relationship in French Polynesia with the Superswell, requires that the chemical or thermal anomalies that produce them reside beneath the moving lihosphere. Since the evidence for the presence of recycled material in the sublithospheric mantle of French Polynesia has been particularly compelling ever since the early work of White and Hofmann [1982] and is reinforced by the conclusions of the present work, we are tempted to associate the temperature anomaly of the Superswell with a locally higher proportion of disseminated crustal debris in the underlying asthenosphere, which is then sampled by the ascending Polynesian hotspot plumes. That no signature of this crustal material is seen along the East Pacific Rise could be explained as either because the rise has never crossed the Superswell (at present the rise is on the eastern limit of the Superswell [McNutt and Fischer, 1987] or because the crustal material is located too deep to be sampled by the MORB magmatism.

\section{CONCLUSIONS}

Submarine volcanoes are presently erupting alkalic lavas (basalts and more evolved trachytic and phonolitic magmas) southeast of Tahiti. The lava compositions suggest that they were produced by mixing between two components, one of which has $\mathrm{Sr}-\mathrm{Nd}$ isotopic ratios similar to many Hawaiian lavas but which has $\mathrm{Pb}$ isotopic ratios much more radiogenic than Hawaii, and the other of which is a source enriched in an old, subduction-derived continental component. This recycled continental component gives rise to higher $\mathrm{SiO}_{2}, \mathrm{Rb} / \mathrm{Nb}, \mathrm{Pb} / \mathrm{Ce},{ }^{87} \mathrm{Sr} / 86 \mathrm{Sr}$, and $\mathrm{Pb}$ isotopic ratios, and lower ${ }^{143} \mathrm{Nd} /{ }^{144} \mathrm{Nd}$ in the lavas, while lead isotopic evidence suggests that it is over 1 b.y. old. On geochemical grounds we have shown that the lavas have no significant contribution from the MORB lithosphere of the Pacific plate.

Moua Pihaa volcano is an exception to the geochemical trends. The lower REE slopes and the higher $206 \mathrm{~Pb} / 204 \mathrm{~Pb}$ of these lavas hints at subducted altered oceanic crust in their source.

The maximum contribution of material from the subduction component varies from volcano to volcano. The contribution seems to be greater in the north than in the south. The geographical variations of maximum $\mathrm{SiO}_{2}$ in the volcanics, although controlled to some extent by the subduction component contribution to the basalts, is mainly affected by the extreme fractionation stages reached on some volcanoes. From the samples so far collected, it appears that these extreme fractionation stages are achieved preferentially on volcanoes situated near the centre of the active region.

The Society hotspot is situated near the margin of the Pacific Superswell. The absence of a MORB component in the Societies, together with the absence of a concentration of volcanism near the center of the Superswell suggests that the latter is not caused by a large-scale mantle upwelling (a superplume). It seems more likely that the Superswell overlies a region of asthenosphere anomalous which is anomalously hot due to a higher concentration of recycled continental debris. 
Acknowledgements. Thanks to D. Dautel for constant help in the lab and with the mass spectromeiry, to M. Vernet and L. Marin for the major element analyses, to K.G. Cox for permission to perform the XRF analyses at Oxford, to J.-L. Zimmerman for his diligent attempts to date the MORB glasses, to R. Hekinian for microprobe data and $\mathrm{P}$. Vidal for $\mathrm{Pb}$ isotopic and concentration data, to C. Alibert, R. Brousse, M. Chaussidon, A. Hofmann, W. F. McDonough, C. Mitchell, J-J Royer, W.Smith, M. Vernet, and A. Zindler for stimulating discussions and valuable help at various stages of the work. We thank Jon Davidson, Al Hofmann, and Bill White for their very helpful reviews, and for showing us the best ways to demonstrate why we don't always agree with them. The Captains and crew of both ships are thanked for their able assistance with the sampling. The Royal Society of London granted a European Fellowship which financed C.W.D.'s stay at the CRPG, where the laboratory work is funded by ATPCNRS grant "Géologie et Géophysique des Océans". The Charcot cruise was funded by the CNRS (France), and the Sonne cruise by the BMFT, Germany (grant 03 R374 A6). This German-French collaboration was greatly facilitated by a PROCOPE travel grant. CRPG Contribution 1001.

\section{REFERENCES}

Alibert, C., A. Michard and F. Albarède, The transition from alkali basalts to kimberlites: Isotope and trace element evidence from melilitites, Contrib. Mineral. Petrol., 82 , 176-186, 1983.

Anderson, D.L., Isotopic evolution of the mantle: The role of magma mixing, Earth Planet. Sci. Lett., 57, 1-12, 1982.

Bargar, K.E., and E.D. Jackson, Calculated volumes of individual sheild volcanoes along the Hawaiian-Emperor chain, J. Res. U.S. Geol. Surv. J., 2, 545-550, 1974.

Barrett, T.J., Lead and strontium isotopic composition of some metalliferous and pelagic sediments and basalts from the Galapagos Mounds area, DSDP leg 70, Initial Rep. Deep Sea Drill. Proj., 70, 325-332, 1983.

Barrett, T.J., P.N. Taylor, I. Jarvis and J. Lugowski, $\mathrm{Pb}$ and $\mathrm{Sr}$ isotope and rare earth element compositions of selected metalliferous sediments from sites 597 to 601, DSDP leg 92, Initial Rep. Deep Sea Drill Proj., 92, 391-407, 1986.

Ben-Avraham, Z., A. Nur, D. Jones and A. Cox, Continental accretion: From oceanic plateaus to allochthonous terranes, Science, 213, 47-54, 1981.

Ben Othman, D., W.M. White and J. Patchett, The geochemistry of marine sediments, island arc magma genesis and crust-mantle recycling, Earth Planet. Sci. Lett., 94, 1-21, 1989.

Brousse, R., G. Boutault, A. Einsenstein and P. Gelugne, Notice explicative de la carte de Tahiti, feuille Papeete, 46 pp., Minist. de l'équip., de l'aménagement, de l'énerg. et des mines, Papeete, 1985.

Calmant, S., and A. Cazenave, The effective elastic lithosphere under the Cook-Austral and Society islands, Earth Planet. Sci. Lett., 77, 187-202, 1986.

Cheminée, J.L., R. Hékinian, J. Talandier, F. Albarède, C.W. Devey, J. Franchteau and Y. Lancelot, Geology of an active hot-spot: Teahitia-Mehetia region of the south central Pacific, Mari. Geophys. Res., 11, 27-50, 1989.

Chen, C.-Y., and F.A. Frey, Trace element and isotopic geochemistry of lavas from Haleakala volcano, East Maui, Hawaii: Implications for the origin of Hawaiian basalts, $J$. Geophys. Res., 90, 8743-8768, 1985.

Cohen, R.S., and R.K. O'Nions, Identification of recycled continental material in the mantle from $\mathrm{Sr}, \mathrm{Nd}$, and $\mathrm{Pb}$ isotope investigations, Earth Planet. Sci. Lett., 61, 73-84, 1982.

Craig, H., Introduction (to special issue on Loihi seamount), Earth Planet. Sci. Lett., 66, 334-336, 1983.
Duncan, R.A., and I. McDougall, Linear volcanism in French Polynesia, J. Volcanol. Geotherm. Res., 1, 197-227, 1976.

Duncan, R.A., M.T. McCulloch, H.G. Barsczus and D.R. Nelson, Plume versus lithospheric sources for melts at Ua Pou, Marquesas Islands, Nature, 322, 534-538, 1986.

Dunn, T., and I.S. McCallum, The partitioning of $\mathrm{Zr}$ and $\mathrm{Nb}$ between diopside and melts in the system diopside-albiteanorthite, Geochim. Cosmochim. Acta, 46, 623-630, 1982.

Dupré, B., and C.J. Allègre, $\mathrm{Pb}-\mathrm{Sr}$ isotope variation in Indian Ocean basalts and mixing phenomena, Nature, 303, 142146, 1983.

Dupuy, C., P. Vidal, H.G. Barsczus and C. Chauvel, Origin of basalts from the Marquesas archipelago (south central Pacific Ocean): Isotope and trace element constraints, Earth Planet. Sci. Lett., 82, 145-152, 1987.

Evensen, N. M., P.J. Hamilton and R.K. ONions, Rare-earth abundances in chondritic meteorites, Geochim. Cosmochim. Acta, 42, 1199-1212, 1978.

Feigenson, M.D., Geochemistry of Kauai volcanics and a mixing model for the origin of Hawaiian alkali basalts, Contrib. Mineral. Petrol., 87, 109-119, 1984.

Fisk, M.R., B.J.G. Upton and C.E. Ford, Geochemical and experimental study of the genesis of magmas of Réunion Island, Indian Ocean, J. Geophys. Res., 93, 4933-4950, 1988.

Gast, P.W., Trace element fractionation and the origin of tholeiitic and alkaline magma types, Geochim. Cosmochim. Acta, 32, 1057-1086, 1968.

Geist, D.J., W.M. White and A.R. McBirney, Plumeasthenosphere mixing beneath the Galapagos archipelago, Nature, 333, 657-660, 1988.

Green, D.H., and A.E. Ringwood, The genesis of basaltic magmas, Contrib. Mineral. Petrol., 15, 103-190, 1967.

Hart, S.R., A large-scale isotope anomaly in the Southern hemisphere mantle, Nature, 309, 753-757, 1984.

Hart S.R., and K.E. Davis, Nickel partitioning between olivine and silicate melt, Earth Planet. Sci. Lett. , 40, 203-219, 1978.

Hofmann, A.W., and W.M. White, Mantle plumes from ancient oceanic crust, Earth Planet. Sci. Lett., 57, 421-436, 1982.

Hofmann, A.W., K.P. Jochum, M. Seufert and W.M. White, Nb and $\mathrm{Pb}$ in oceanic basalts: New constraints on mantle evolution, Earth Planet. Sci. Lett., 79, 33-45, 1986.

Irving, A.J., A review of experimental studies of crystal/liquid trace element partitioning, Geochim. Cosmochim. Acta, 42, 743-770, 1978.

Irving, A.J., and R.C. Price, Geochemistry and evolution of lherzolite-bearing phonolitic lavas from Nigeria, Australia, East Germany, and New Zealand, Geochim. Cosmochim. Acta, 45, 1309-1320, 1981.

Ito, E., W.M. White and C. Göpel, The O, Sr, Nd and $\mathrm{Pb}$ isotope geochemistry of MORB, Chemical Geology, 62, 157-176, 1987.

Jaques, A.L., and D.H. Green, Anhydrous melting of peridotite at $0-15 \mathrm{~kb}$ pressure and the genesis of tholeiitic basalts, Contrib. Mineral. Petrol., 73, 287-310, 1980.

Kushiro, I., The system forsterite-diopside-silica with and without water at high pressures, Am. J. Sci., 267A, 269 294, 1969.

La Roche, H., J. Leterrier, P. Grandclaude and M. Marchal, A classification of volcanic and plutonic rocks using $R_{1}-R_{2}$ daigram and major element analyses-Its relationships with current nomenclature, Chem. Geol., 29, 183-210, 1980.

Macdougall, J.D., and G.W. Lugmair, $\mathrm{Sr}$ and $\mathrm{Nd}$ isotopes in basalts from the East Pacific Rise: significance for mantle heterogeneity, Earth Planet. Sci. Lett., 77, 273-284, 1986.

Manhes, G., J.F. Minster and C.J. Allègre, Comparative uranium-thorium-lead and rubidium-strontium of St. Severin 
amphoterite: Consequences for early solar system chronology, Earth Planet. Sci. Lett., 39, 14-24, 1978.

McBirney, A.R., and K.-I. Aoki, Petrology of the island of Tahiti, Mem. Geol. Soc. Am. , 116, 523-556, 1968.

McNutt, M.K., and K.M. Fischer, The South Pacific superswell, in Seamounts, Islands, and Atolls, Geophys. Monogr. Ser., vol. 43, edited by B.H. Keating, P. Fryer, R. Batiza, and G.W. Boehlert, pp. 25-34, AGU, Washington, D.C.,1987.

Menzies, M.A., and C.J. Hawkesworth, Upper mantle processes and composition, in Mantle Xenoliths, edited by P.H. Nixon, pp. 725-738, John Wiley, New York, 1987.

Michard, A., and F. Albarède, Hydrothermal uranium uptake at ridge crests, Nature, 317, 244-246, 1985.

Michard, A., P. Gurriet, M. Soudan and F. Albarède, Nd isotopes in French Phanerozoic shales: external vs. internal aspects of crustal evolution, Geochim. Cosmochim. Acta , 49, 601-610, 1985.

Michard, A., R. Montigny and R. Schlich, geochemistry of the mantle beneath the Rodriguez Triple Junction and the South-East Indian Ridge, Earth Planet. Sci. Lett., 78, 104114, 1986.

Moore, J.G., D.A. Clague and W.R. Normark, Diverse basalt types from Loihi seamount, Hawaii, Geology, 10, 88-92, 1982.

Morgan, W.J., Deep mantle convection plumes, and plate mótions, Am. Assoc. Pet. Geol. Bull., 56, 203-213, 1972.

Nagasawa, H., and C.C. Schnetzler, Partitioning of rare earth, alkali and alkaline earth elements between phenocrysts and acidic igneous magma, Geochim. Cosmochim. Acta, 35 , 953-968, 1971.

Nicholls, I.A., and A.E. Ringwood, Effect of water on olivine stability in tholeiites and the production of silica-saturated magmas in the island-arc environment, J. Geol., 81, 285 $300,1973$.

Okal, E.A., J. Talandier, K.A. Sverdrup and T.H. Jordan, Seismicity and tectonic stress in the south central Pacific, J. Geophys. Res., 85, 6479-6495, 1980.

Palacz, Z.A., and A.D. Saunders, Coupled trace element and isotope enrichment in the Cook-Austral-Samoa islands, southwest Pacific, Earth Planet. Sci. Lett., 79, 270-280, 1986.

Perfit, M.R., D.A. Gust, A.E. Bence, R.J. Arculus and S.R. Taylor, Chemical characteristics of island-arc basalts: Implications for mantle sources, Chem. Geol., 30, $227-$ 256, 1980.

Roden, M.F., F.A. Frey and D.A. Clague, Geochemistry of tholeiitic and alkalic lavas from the Koolau Range, Oahu, Hawaii: Implications for Hawaiian volcanism, Earth Planet. Sci. Lett., 69, 141-158, 1984.

Roeder, P.L., and R.F. Emslie, Olivine-liquid equilibrium, Contrib. Mineral. Petrol., 29, 275-289, 1970.

Smith, W.H.F., H. Staudigel, A.B. Watts and M.S. Pringle, The Magellan Seamounts: Early Cretaceous record of the South Pacific isotopic and thermal anomaly, J. Geophys. Res., 94, 10,501-10,523, 1989.

Staudigel, H., A. Zindler, S.R. Hart, T. Leslie, C.-Y. Chen and D. Clague, The isotope systematics of a juvenile intraplate volcano: $\mathrm{Pb}, \mathrm{Nd}$, and $\mathrm{Sr}$ isotope ratios of basalts from Loihi seamount, Hawaii, Earth Planet. Sci. Lett., 69, 13-29, 1984.

Stille, P., D.M. Unruh and M. Tatsumoto, $\mathrm{Pb}, \mathrm{Sr}, \mathrm{Nd}$, and $\mathrm{Hf}$ isotopic evidence of multiple sources for Oahu, Hawaii basalts, Nature, 304, 25-29, 1983.

Stoffers, P., Cruise report SONNE 47-Midplate volcanism central South Pacific, French Polynesia. Tahiti-Tahiti, 27.12.1986-2.2.1987, Ber.Rep. Geol. Inst. Univ. Kiel, 19, 180 pp., 1987.

Sun, S.S., M. Tatsumoto and J.G. Schilling, Mantle plume mixing along the Reykjanes ridge axis: Lead isotopic evidence, Science, 190, 143-147, 1975.

Talandier, J., and E.A. Okal, The volcanoseismic swarms of 1981-1983 in the Tahiti-Mehetia area, French Polynesia, J. Geophys. Res., 89, 11,216-11,234, 1984.

Tatsumoto, M., Isotopic composition of lead in oceanic basalt and its implication to mantle evolution, Earth Planet. Sci. Lett., 38, 63-87, 1978.

Tatsumoto, M., E. Hegner and D.M. Unruh, Origin of the West Maui volcanic rocks inferred from $\mathrm{Pb}, \mathrm{Sr}$, and $\mathrm{Nd}$ isotopes and a multicomponent model for oceanic basalts, Volcanism in Hawaii, edited by R.W. Decker, T.L. Wright and P.H. Stauffer, U.S. Geol. Surv. Prof. Pap., 1350, 723744, 1987.

Thirlwall, M.F., and A.M. Graham, Evolution of high-Ca, high-Sr C-series basalts from Grenada, Lesser Antilles: The effects of intra-crustal contamination, J. Geol. Soc. London, 141, 427-445, 1984.

Thompson, R.N., Phase equilibria constraints on the genesis and magmatic evolution of oceanic basalts, Earth Sci. Rev., 24, 161-210, 1987.

Vidal, P., C. Chauvel and R. Brousse, Large mantle heterogeneity beneath French Polynesia, Nature, 307, 536538, 1984.

Watson, E.B., and F.J. Ryerson, Partitioning of zirconium between clinopyroxene and magmatic liquids of intermediate composition, Geochim. Cosmochim. Acta, 50, 2523-2526, 1986.

West, H.B., and W.P. Leeman, Isotopic evolution of lavas from Haleakala Crater, Hawaii, Earth Planet. Sci. Lett., 84, 211-225, 1987.

West, H.B., D.C. Gerlach, W.P. Leeman and M.O. Garcia, Isotopic constraints on the origin of Hawaiian lavas from the Maui Volcanic Complex, Hawaii, Nature, 330, 216-220, 1987.

White, W.M., and A.W. Hofmann, $\mathrm{Sr}$ and $\mathrm{Nd}$ isotope geochemistry of oceanic basalts and mantle evolution, Nature, 296, 821-825, 1982.

White, W.M., A.W. Hofmann and H. Puchelt, Isotope geochemistry of Pacific mid-ocean ridge basalt, $J$. Geophys. Res., 92, 4881-4893, 1987.

Williams, H., Geology of Tahiti, Moorea and Maiao, B.P. Bishop Mus. Bull., 105, 1-89, 1933.

Wright, E., and P.C. Doherty, A linear programming and leastsquares computer method for solving petrologic mixing problems, Geol Soc. America Bull., 81, 1995-2008, 1970.

Wright, E., and W.M. White, The origin of Samoa: New evidence from $\mathrm{Sr}, \mathrm{Nd}$, and $\mathrm{Pb}$ isotopes, Earth Planet. Sci. Lett., 81, 151-162, 1987.

Zindler, A., and S. Hart, Chemical geodynamics, Annu. Rev. Earth Planet. Sci., 14, 493-571, 1986.

Zindler, A., E. Jagoutz and S. Goldstein, $\mathrm{Nd}, \mathrm{Sr}$, and $\mathrm{Pb}$ isotopic systematics in a three-component mantle: A new perspective, Nature, 298, 519-523, 1982.

F. Albarède and A. Michard, Centre de Recherches Pétrograhiques et Géochimiques, CNRS, B.P. 20, 54501 Vandoeuvre lès Nancy, France.

J.-L. Cheminée, Observatoire Volcanologique, IPGP, 4, place Jussieu, 75252 Paris, France.

C.W. Devey, R. Mühe, and P. Stoffers, Geologisches Institüt der Universität Kiel, Olshausenstrasse 40, $2300 \mathrm{Kiel}$, Federal Republic of Germany.

(Received April 4, 1989; revised October 10, 1989; accepted October 10, 1989.) 